\title{
A current synthesis on the effects of electric and magnetic fields emitted by submarine power cables on invertebrates
}

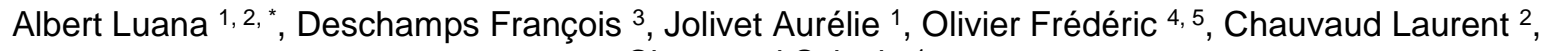 \\ Chauvaud Sylvain ${ }^{1}$
}

1 TBM Environnement, Porte Océane Bloc 03, 2 rue de Suède, 56400, Auray, France

2 Univ. Brest, CNRS, IRD, Ifremer, LEMAR, rue Dumont D'Urville, 29280, Plouzané, France

3 RTE, Immeuble Window, 7C place du Dôme, 92073, Paris La Défense Cedex, France

4 Biologie des Organismes et écosystèmes Aquatiques (BOREA, UMR 7208), MNHN/SU/UNICAEN/UA/CNRS/IRD, 61 Rue Buffon CP53, 75005, Paris, France

5 Station Marine de Concarneau, Muséum National d'Histoire Naturelle, Place de la Croix, BP 225, 29182, Concarneau Cedex, France

* Corresponding author : Luana Albert, email address : l.albert@tbm-environnement.com

francois.deschamps@rte-france.com ; a.jolivet@tbm-environnement.com ; folivier@mnhn.fr ; laurent.chauvaud@univ-brest.fr ; s.chauvaud@tbm-environnement.com

\section{Highlights}

- Submarine power cables produce both magnetic and electric fields. Marine invertebrate species inhabit the benthic or sediment compartment where cables emissions would be the strongest. Studies are scarce and invertebrate sensitivity to both natural and artificial sources of magnetic and electric fields is poorly documented. Marine invertebrates should prioritised in future research studies according to their proximity to the cable and the duration of their exposure. 
1

\section{Introduction}

Magnetic and electric fields are naturally occurring forces in the environment. Many living organisms, such as bacteria, birds, amphibians, insects, reptiles, mammals, and fish, are electroreceptive or magneto-sensitive species that can detect these fields (Wiltschko, 1995; Wiltschko and Wiltschko, 2005). The Earth's magnetic field (or geomagnetic field, GMF) constitutes a primary natural magnetic source that is ubiquitous and continuous, both on land and at sea. Essential functions, such as orientation, homing, and navigation over long migrations and short-range movements, imply the existence of a GMF detection sense, as reviewed by Walker et al. (2003) and Wiltschko (1995). Such magneto-sensitivity occurs in most marine phyla undergoing large-scale migrations, like cetaceans (e.g., Kremers et al., 2014), elasmobranchs (Kalmijn, 1978), teleost fishes (Quinn, 1980; Quinn and Brannon, 1982; Walker, 1984), sea turtles (Lohmann, 1991), decapod crustaceans, or species performing local-scale movements, such as isopod and amphipod crustaceans (e.g., Arendse and Kruyswijk, 1981; Lohmann et al., 1995; Ugolini and Pezzani, 1995). Some work has confirmed that the GMF partly guides the long-distance migrations of eel (Anguilla Anguilla) (Baltazar-Soares and Eizaguirre, 2017; Naisbett-Jones et al., 2017), spiny lobster (Panulirus argus) (Lohmann et al., 1995), steelhead trout (Ochorhyncus mykiss) (Putman et al., 2014a), and loggerhead turtle (Caretta caretta) (Lohmann et al., 2001). Additionally, some species, particularly among elasmobranchs have specialised electroreceptive organs that can detect the bioelectric fields produced by prey, predators, and conspecifics (e.g., Ball et al., 2016; reviewed in Tricas and Sisneros, 2004).

However, this 'natural' sensory landscape may be altered by the anthropogenic magnetic and electric fields emitted by electrical conductors (Otremba et al., 2019). While such artificial sources are abundant on land, they remained until now scarce in the oceans. However, they beginning to proliferate in coastal areas due to marine renewable energy devices (MREDs) that convert renewable sources of energy (i.e., wind, waves, tides, and water currents) into electricity (Gill et al., 2014). Furthermore, projects to electrically interconnect countries are already being planned (Rte, 2019). The greatest concerns from operating mode MREDs relate to both magnetic and electric emissions into the marine environment, mainly resulting from submarine power cables (SPCs) supporting the electricity 
1 transfer (Taormina et al., 2018). Among $8000 \mathrm{~km}$ of high-voltage direct current cables (HVDC) covering the seabed, $70 \%$ are located in European seas. In the near future, we can anticipate a gigantic cable network on the seafloor in the vicinity of developed countries, particularly in small oceanic basins (e.g., the Baltic Sea, Northern Sea, and Mediterranean Sea) (Ardelean and Minnebo, 2015).

Submarine power cables produce both magnetic and electric fields that may either interact with the geomagnetic field or coexist independently (Otremba et al., 2019). Such artificial sources may mask or alter natural magnetic and electric cues, thereby impacting the ecological processes in sensitive species, such as spawning or feeding migrations, homing, predation, and detection of sexual mates (Klimley et al., 2016; Tricas and Gill, 2011; Öhman et al., 2007). Recently, concerns have been raised regarding the emissions of SPCs and their potential to cause attraction or repulsion, barriers to local movements or long-distance migrations, disorientation, or behavioural and physiological changes (reviewed in Fischer and Slater, 2010). Experimental studies addressing such issues have focused on short-term behavioural and physiological responses as well as effects on development. Organisms' survival is unaffected by SPCs' magnetic emissions (Bochert and Zettler, 2004). When considering behavioural responses, field studies mainly conducted on teleost fish species revealed no evidence that magnetic fields act as permanent barriers to long-range migrations of either Chinook salmon (Oncorhynchus tshawytscha), green sturgeon (Acipenser medirostris), or European eel (Anguilla Anguilla) (Klimley et al., 2016; Öhman et al., 2007; Westerberg and Lagenfelt, 2008; Wyman et al., 2018). Testing the attractionrepulsion towards magnetic fields has been a goal for other studies, and these produced contrasting results between members of taxonomic groups (i.e., crustaceans, molluscs, fish, elasmobranchs, polychaetes) and different species (e.g., Bevelhimer et al., 2015, 2013; Cada et al., 2011; Gill et al., 2009; Hutchison et al., 2018; Jakubowska et al., 2019; Scott et al., 2018). Focusing on embryos and larval stages of teleost fishes, no magnetic field effects were found on embryonic or larval mortality, growth, and hatching success of Atlantic halibut (Hippoglossus hippoglossus), California flounder (Paralichtys californicus), Northern pike (Esox Lucius), and rainbow trout (Onchorhyncus mykiss) (Fey et al., 2019ab; Woodruff et al., 2012). In contrast, magnetic fields caused a shortening in the hatching time in Northern pike embryos (Esox lucius) and an enhanced yolk-sac absorption rate, also observed in 
rainbow trout (Onchorhyncus mykiss) (Fey et al., 2019ab). Also, magnetic fields delayed embryo growth and increased developmental abnormalities in invertebrate sea urchins Lytechinus pictus and Strongylocentrotus purpuratus (Levin and Ernst, 1997; Zimmerman et al., 1990).

Although the field of research concerning the effects of artificial magnetic fields on marine fauna is gradually growing, it appears to be restricted to specific taxa. To date, invertebrate species (i.e., mollusc, worms, crustaceans and echinoderms) have been poorly studied. Specifically, fundamental data about the magneto-sensitivity of some invertebrate groups are lacking, creating a knowledge void regarding the impact assessment of magnetic field exposure (Emma, 2016; Isaacman and Lee, 2009; Tricas and Gill, 2011). In addition, invertebrate burrowing and epibenthic species, such as bivalves, decapods, and worms, should more frequently encounter cable-generated fields, since they live on or near the seafloor where exposure is highest. In particular, invertebrates include a high proportion of low-motility and sessile organisms that are likely to experience long-term exposure if located close to SPCs (Michel et al., 2007). Marine benthic invertebrates play crucial roles in coastal ecosystem functioning; for example, they regulate nutrient fluxes at the water-sediment interface (e.g., detrital food decomposition and nutrient redistribution through consumption, egestion, and sediment reworking) (Prather et al., 2013). They also ensure oxygen and water penetration into sediments by their bioturbation activities (burrowing and bio-irrigation) and contribute to carbon and nitrogen cycles through their excretion (Snelgrove, 1997). Accordingly, in light of the current spatial expansion of the SPC network, there is a crucial need to assess the effects of SPC magnetic fields on marine invertebrates.

This review intends to cover the available literature on the interactions of artificial and natural sources of electric and magnetic fields with marine invertebrates. With the context of current energy challenges, this review aims to synthesise the effects of magnetic and electric fields emitted by submarine power cables. In the first section, we provide extensive background knowledge on natural and anthropogenic sources of magnetic and electric fields in the marine environment. We then detail mechanisms underlying magnetoand electro-sensitivity and review some key studies demonstrating that marine invertebrates detect natural magnetic and electrical signals. We further highlight what is currently known about the interactions of marine invertebrates with magnetic and electric 
1 fields generated by SPCs. Finally, we discuss the main gaps and future challenges that

2 require further investigation.

\section{1. Electric and magnetic fields in the marine environment}

\subsection{Natural and artificial sources}

Whereas electric fields (expressed in $\mathrm{mV} / \mathrm{m}$ ) originate from voltage differences, magnetic fields (expressed in $\mu \mathrm{T}$ ) are created from the flow of an electric current and thus coexist with the associated electric field. Electric and magnetic fields naturally occur in the marine environment and are characterised by their frequency, expressed in hertz $(\mathrm{Hz})$, which is the number of times per second the field changes direction.

Natural sources of magnetic fields, specifically the geomagnetic field (GMF), are direct current (DC) fields and thus have a constant direction (i.e., null frequency). The major source, accounting for $95 \%$ of the magnetic strength at the Earth's surface, is caused by the convective movement of molten iron inside the Earth's core (Heilig et al., 2018). This socalled core field varies with latitude between $20-30 \mu \mathrm{T}$ at the equator and $60-70 \mu \mathrm{T}$ at the poles (50 $\mu \mathrm{T}$ at mid-latitudes) (Wiltschko, 1995). Another much smaller source (on average $20 \mathrm{nT}$ ) originates from the scattered distribution of magnetised materials inside the crustal; thus, it is called the crustal field. The core and crustal fields together form the internal field and vary on timescales of years to millennium. The external field includes several sources arising from solar-terrestrial interactions (e.g., electrical currents in the ionosphere and magnetosphere) and from ocean water currents that may form electrical currents and their associated magnetic fields ( 1 to $100 \mathrm{nT}$ ) (see details in Gill et al., 2014; Olsen et al., 2010; Tyler et al., 2003). Therefore, the GMF varies on timescales of seconds to days with a magnitude of pT to $100 \mathrm{nT}$ and can reach thousands of nT (e.g., during geomagnetic storms) (Heilig et al., 2018).

The dominant source of marine electric fields results from the law of electromagnetic induction: any movement through the GMF, by an organism or an ocean current that are electrical conductors, induces a weak DC electric field (about $0.075 \mathrm{mV} / \mathrm{m}$ in the case of an ocean current moving through the GMF) (CSA Ocean Sciences Inc. and Exponent, 2019). Additionally, marine organisms are surrounded by alternating current (i.e. with non-null 
1 frequency, $A C$ ) and DC electric fields up to $500 \mathrm{mV} / \mathrm{m}$, called bioelectric fields, that occur at

2 frequencies less than $10 \mathrm{~Hz}$ and are strongly attenuated within 10 or $20 \mathrm{~cm}$ from the animal

3 source (Bedore and Kajiura, 2013).

4

In the last few decades, artificial electric and magnetic fields have been introduced to the marine environment by the immersion of electric conductors in the ocean. Whereas artificial static magnetic fields are partly induced by bridges or electrical equipment aboard vessels and are therefore particularly strong in busy shipping lanes, their dominant sources originate from both communication and submarine power cables (SPCs) (Ardelean and Minnebo, 2015; Kavet et al., 2016). Their total length on the seabed reaches $10^{6} \mathrm{~km}$, mainly composed of communication cables. Although telecommunication (i.e., fibre optical) cables cover a large area of the seabed, their electric and magnetic emissions are substantially smaller than those of SPCs (Carter et al., 2009; Meißner et al., 2006; Tricas and Gill, 2011). The total voltage required for a typical $7500 \mathrm{~km}$ transatlantic telecommunication cable, equipped with 100 repeaters (used to maintain the optical signal), is around $10 \mathrm{kV}$ (no magnetic field measurements found) (Meißner et al., 2006).

\subsection{Submarine power cables (SPCs)}

\subsubsection{General features}

SPCs have various purposes, such as supplying power to islands or oil platforms, transferring electricity from marine renewable energy devices (MREDs), and providing electrical interconnections between countries (autonomous grid connexion); the latter two carry the strongest electrical currents (Taormina et al., 2018; Worzyk, 2009). With rare exceptions, SPCs do not exceed $300 \mathrm{~km}$ in length and are located in coastal areas up to the beginning of bathyal areas (<500 m depth) (Ardelean and Minnebo, 2015). When operational, SPCs generate both electric and magnetic fields. Electric fields are confined to the internal part of the cable through the use of highly conductive sheathes and armour, such as steel plates, wire, or tape. In contrast, existing insulation technology is only partially effective in shielding magnetic emissions and is currently not taken into account in the design of cables. In terrestrial structures magnetic emissions may be tempered by absorption or deflexion tools (CSA Ocean Sciences Inc. and Exponent, 2019) that are 
1 inoperable in the marine environment because of sea water corrosion (data communicated by the French transmission system operator Rte). With the absorption procedure, materials of high electrical conductivity are used as cable armour or sheaths to reduce the magnetic field by the 'skin effect' principle: eddy currents created in the conductive material produce locally opposing magnetic fields that partially cancel the cable's field (Ardelean and Minnebo, 2015; CMACS, 2003; Exponent Inc., 2013; CSA Ocean Sciences Inc. and Exponent, 2019) . Silva et al. (2006) (in Exponent Inc., 2013) predicted that magnetic emissions of a 138 $\mathrm{kV}$ AC submarine cable would be cut in half through this procedure. With the deflexion procedure, high permeability ferromagnetic materials are used to trap magnetic fluxes, creating a magnetic circuit that reduces magnetic transfers outside the armour.

\subsubsection{The intensity of magnetic and electric fields}

The intensity of artificial electric (expressed in $\mathrm{mV} / \mathrm{m}$ ) and magnetic fields (also called magnetic induction, expressed in $\mu \mathrm{T}$ ), depends on several factor and have similar variations, with the characteristics of the power transmission line being of major importance. Next paragraphs focus on the magnetic field, as it radiates outside the cable. In the literature, the magnetic induction is determined either from calculations or from in situ measurements (Table 1).

First, SPCs operate with two power supply systems, either AC or DC (Worzyk, 2009). For $\mathrm{AC}$ cables, the magnetic field varies at low frequencies $(50 \mathrm{~Hz}$ in Europe and $60 \mathrm{~Hz}$ in North America) and, since it is not shielded, induces a weak alternating electric field in the surrounding ocean (i.e., 'induced electric field') (Ardelean and Minnebo, 2015; Copping et al., 2016). DC cables produce a static magnetic field that interacts with the ambient GMF, and the resulting magnetic field increases or decreases in relation with its geographic alignment (see details in Otremba et al., 2019).

Second, the magnetic induction increases linearly with the intensity of the current flow in the cable, dependent on its power and voltage. This means that the increase (or decrease) in the current flow results in an increase (or decrease) of both DC and AC magnetic fields and, if so, of the induced electric field. As a consequence, systems with the highest capacities for current transfer are likely to generate strong field emissions (Meißner et al., 2006). Thanks to improved insulation technology, high-voltage SPCs require less current to 
supply power than a cable of lower voltage, resulting in a reduction in their magnetic emissions. Long-distance and high-voltage electricity transmissions are commonly made with DC cables to reduce energy losses that increase with length in AC transmission (CSA Ocean Sciences Inc. and Exponent, 2019). For example, most power lines connecting power grids of different countries are 'high-voltage direct current' (HVDC) lines.

Third, the magnetic induction decreases with distance from the cable (Table 1). Whenever possible, cables are buried under a sediment layer $(0.3$ to $2 \mathrm{~m})$ to minimise risks of damage due to anchors of trawling ships. The deeper the cable is buried, the weaker the magnetic field and induced electric field encountered by the benthic and pelagic fauna. In turn, buried cables increase the magnetic exposure of burrowing species. In the case of hard substrata or deep water ( $600 \mathrm{~m}$ ), cables simply lay on the seabed and are covered by dumped rocks, steel plates, concrete slab mattresses, cast-iron shells, or cable anchoring (15 to $30 \mathrm{~cm}$ thick) (Meißner et al., 2006; Taormina et al., 2018) that provide suitable substrata for biological colonisation of sessile or vagile organisms (Isaacman and Lee, 2009).

Finally, the number of conductors (also expressed as phases) inside a cable can affect the magnetic induction. In multi-conductor cables (i.e., three-phase AC or bipolar DC cables), anti-directional magnetic fields (i.e., current flowing in opposite direction) can largely cancel each other out if located as close as possible and parallel to each other. The magnetic field of the conductors is almost nullified at the surface of the cable, since the sum of both voltages and currents of the phases is zero at any one time. For example, when a pair of HVDC cables carries $1000 \mathrm{~A}$ and are separated by $0.1 \mathrm{~m}$, the magnetic field is far below $1 \mu \mathrm{T}$ at $11 \mathrm{~m}$ above the cable. But when the distance between the cables is $10 \mathrm{~m}$, the magnetic field is 10 $\mu \mathrm{T}$ at $11 \mathrm{~m}$ above the cable (Worzyk, 2009). In single-phase AC or monopolar DC cables, the magnetic cancellation effect does not occur as cables are commonly spaced 10 to $100 \mathrm{~m}$, for technical reasons (i.e avoiding heating points between the two cables and ensuring that one of the two cables is in operation in case the other would be damaged) (Johansson et al., 2005). Additionally, helically twisting of the conductors also helps to temper overall magnetic emissions (e.g., by a factor of 10 compared to an untwisted cable) (CSA Ocean Sciences Inc. and Exponent, 2019).

\subsubsection{Case of offshore wind farms}


Globally, offshore wind facilities present a leading renewable technology and thus require the greatest number of SPCS (Sun et al., 2012). Generally, they comprise one power generation system and one power transmission system (Wei et al., 2017) (Figure 1).

The power generation system consists of inter-turbine cables $(15.5$ to $16.5 \mathrm{~cm}$ in diameter) that collect the power from all wind turbine generators. In the United Kingdom, the Walney extension wind farm features 87 wind turbines. Their output is normally less than $1000 \mathrm{~V}$ (e.g., 690 or $900 \mathrm{~V}$ ) (Natural power, 2015). The collection cables bring the electricity of all turbines into a step-up transformer chain, where the power is stepped up to medium-voltage (33-36 kV) and then high-voltage levels. The in-field cables (inter-turbine and collecting cables) are usually AC three-phase medium voltage cables (10-36 kV) (Ardelean and Minnebo, 2015; Worzyk, 2009). Finally, the power reaches the offshore collection point. If needed, this is where the high-voltage AC (HVAC) level might be converted into a high-voltage $D C$ (HVDC) level by an AC/DC power converter station. However, offshore substations are very costly and are dedicated to high-production wind farms (Wei et al., 2017). As much as possible, in-field cables are buried in the sediment (0.9 to $1.8 \mathrm{~m}$ ) and are protected by J-tubes at the substation and turbine foundations (CMACS, 2003; CSA Ocean Sciences Inc. and Exponent, 2019; Natural power, 2015). For example, the world's largest operational windfarm, the Walney extension in the Irish Sea, covers an area of $145 \mathrm{~km}^{2}$.

The power transmission system is composed of export cables $(20$ to $30 \mathrm{~cm}$ in diameter) that link the offshore collection point to the shore, and they are usually 138-230 kV (CSA Ocean Sciences Inc. and Exponent, 2019). When this distance is less than $50 \mathrm{~km}$, HVAC cables are the most economic and convenient option (Wei et al., 2017). However, DC transmission is preferred for distances greater than $50 \mathrm{~km}$ but is more costly and requires HVDC converter stations. While the diameter and voltage of inter-array cables are smaller than for export cables, the current flows and thus the magnetic emissions are quite similar. 
1

2

3

4

5

6

7

8

\section{Interactions of marine invertebrates with electric and magnetic}

\section{fields}

The marine environment offers a diversity of cues (chemical, physical, biological and acoustical) that marine species use to locate or remain in a suitable habitat. Among these, the GMF provides spatial information of potential relevance for the marine fauna, particularly when other orientation cues are lacking, such as in the open ocean. Two main bases support this assumption: (1) unlike other cues, the GMF remains regular over ecological time regardless of the season, weather, depth, or light and (2) local and regional variations in lithology and topography features (e.g., coastline, islands, and seamounts) induce singular magnetic signatures of potential value for the orientation and navigation of organisms (Lohmann and Ernst, 2014). Migrating marine species could thus navigate using geomagnetic cues through magnetoreception. At a single location, GMF is characterised by its (1) horizontal and vertical field intensities, (2) total field intensity (i.e., sum of the two previous vectors), and (3) inclination angle between the total field intensity vector and the Earth's surface (see Lohmann et al., 2007). The so-called 'magnetic compass species' extract directional or compass cues to maintain headings relative to the magnetic poles (i.e., either South or North) (Lohmann et al., 2007; Wiltschko and Wiltschko, 2005). Some marine turtles use an 'inclination compass' based on the inclination angle (e.g., Light et al., 1993; Lohmann and Lohmann, 1994), while fishes and crustaceans use a 'polarity compass' based on the horizontal field intensity (e.g., Lohmann et al., 1995; Quinn and Brannon, 1982). In contrast, 'magnetic map species', such as turtles and salmonids, have the ability to derive positional information and to adjust their swimming direction towards their goal (Avens and Lohmann, 2004; Lohmann et al., 2012; Putman et al., 2014b). Such a cue is provided by the predictable variation in the magnetic field intensity and inclination angle as a function of latitude and longitude (Putman et al., 2011).

The marine environment is one of the rare habitats allowing the propagation of electric fields, mainly detected by vertebrate species (e.g., elasmobranchs, chondrosteans, agnathans, sarcopterygians, some teleost fishes, and one cetacean species) through passive electroreception, ensured by electroreceptive organs (ampullae of Lorenzini) (reviewed in Collin, 2019; Czech-Damal and Dehnhardt, 2013). Electroreception is usually a short-range 
1 sense (from a few to tens of centimetres) and is effective for detecting the bioelectric fields of predators, preys, and conspecifics (Bullock et al., 2005). This sense is also assumed to play a role in navigation and orientation behaviours through the electromagnetic induction mechanism (detailed in Section 2.1) (Kalmijn, 1982). Here, we give a brief overview of the mechanisms underlying magneto- and electroreception in marine invertebrates.

\subsection{Mechanisms of magneto and electroreception}

Mechanisms behind magnetoreception have not been clearly established in any marine invertebrate, but in recent years, magnetite reception, chemical magnetoreception, and electromagnetic induction hypotheses have been discussed (Johnsen and Lohmann, 2008; Nordmann et al., 2017; Vacha, 2017).

The first hypothesis is based on the detection of magnetite particles (i.e., Fe304, both ferromagnetic materials and electrical conductors) in animal tissues (Lowenstam, 1962), leading to theoretical models. Briefly, as they align under the action of mechanical forces induced by the GMF, either magnetite crystals push on secondary mechano- or hair cells receptors, or else their rotation in cells opens ion channels (e.g., Cadiou and McNaughton, 2010; Eder et al., 2012; reviewed in Shaw et al., 2015; Winklhofer and Kirschvink, 2010). In favour of this mechanism, Ernst and Lohmann (2016) observed orientation changes in Carribbean spiny lobster (Panulirus argus) in response to magnetic pulses that cause magnetite rotation. Natan and Vortman (2017) also proposed that symbiotic magneto-tactic bacteria (containing magnetite particles), capable of detecting the GMF declination angle (angle between geographic and geomagnetic norths), could be the source of magnetosensing in animals.

One other potential mechanism implies that there is a radical-pair photoreceptor involving chemical reactions within the visual system (Ritz et al., 2000; Schulten et al., 1978), with details found in several works (reviewed in Hore and Mouritsen, 2016; Ritz et al., 2010). Simply put, a light stimulus on a cryptochrome, a photoreceptive molecule, induces the formation of a transient radical pair (i.e., pair of molecules with unpaired electrons) that is sensitive to external magnetic fields. This mechanism is well studied in birds (reviewed in Wiltschko and Wiltschko, 2019) and has been recently considered as the leading hypothesis, 
1 since it is supported by chemical, physical, and biological facts (see details in Worster et al., 2 2017).

The third hypothesis relies on Faraday's law of electromagnetic induction (Faraday, 1832) and proposes that any movement of an animal in a constant magnetic field will induce a constant voltage inside an electrically conductive part of its body. Hence, a magnetic signal would be converted into an electric stimulus detectable by voltage-sensing cells, such as the electroreceptors of elasmobranch fishes (i.e., ampullae of Lorenzini) (e.g., Kalmijn, 1982; Meyer et al., 2005). This mechanism has not been investigated in invertebrate species, since they have no identified electroreceptors. However, electromagnetic induction has been studied in elasmobranchs and was recently proposed to underlie the navigation of pigeons (Malkemper et al., 2019; Nimpf et al., 2019).

\subsection{Evidence for magneto and electroreception in crustaceans and molluscs}

Much work to date has been conducted on the Caribbean spiny lobster (Panulirus argus), which displays autumnal mass migrations from shallow areas to open waters. Multiple guideposts (i.e., visual, hydrodynamic, acoustical cues, bottom slope) are used by spiny lobsters to maintain directionality through variable conditions (i.e., darkness, topography variations, turbid water, and absence of surge) (Herrnking and McLean, 1971; Nevitt et al., 1995; Walton and Herrnking, 1977). Lohmann et al. (1995) also found evidence of a polarity compass sense (see Section 2), as lobsters were shown to be receptive (i.e., they deviated from their initial course) to a reversal of the horizontal component of the GMF (magnetic north becoming magnetic south). Shortly after, in a series of field experiments, Boles and Lohmann (2003) also demonstrated that spiny lobsters are a magnetic map species. Indeed, after a transfer to distant geographic areas (with visual and vibratory or magnetic cues deprivation), adults of $P$. argus were able to orient with an angle consistent with their original location. Results were similar when individuals were transferred and tested in fields replicating those existing either $400 \mathrm{~km}$ north or south of the test site.

A magnetic compass (i.e., polarity) was also found in isopods and amphipods (reviewed in Lohmann and Ernst, 2014; Ugolini and Pezzani, 1995). Amphipods migrate up and down the beach with the tide along an axis perpendicular to the shoreline. This migration involves a variety of cues (e.g., visual landmarks, sun and moon compass, beach 
1 slope, hydrostatic pressure) whose use depends upon the environmental conditions (i.e., relative humidity, level of light, animal condition, whether feeding of jumping) (Herrnking and McLean, 1971). Several laboratory experiments showed that, under natural magnetic conditions (in complete darkness), sand-hoppers (Talitrus spp) oriented in directions that coincided with the land-sea axis of their home beach (Arendse and Kruyswijk, 1981). Additionally, when the ambient field was rotated (Helmholtz coils), individuals shifted their orientation accordingly, and they oriented randomly when it was cancelled (Arendse and Kruyswijk, 1981; Ugolini and Pardi, 1992). Sand-hoppers (Talorchestia martensii) were also observed to scan the horizontal component of the magnetic field by oscillating their body axis, displaying 'body scanning' (Ugolini, 2006). Subsequent experiments demonstrated that, when solar cues are lacking, amphipods used the GMF as the dominant orientation cue (Ugolini, 2002). Similar findings were reported in the amphipod Orchestia cavimana and the marine isopod Idotea baltica basteri (Arendse and Barendregt, 1981; Ugolini and Pezzani, 1995).

To our knowledge, magneto-sensitivity has only been investigated in a single nudibranch mollusc species, the sea slug (Tritonia tetraquetra, formerly Tritonia diomedea). In a laboratory experiment, Lohmann and Willows (1987) observed the sea slug's orientation inside a Y-maze with arms oriented either southward or eastward under an ambient magnetic field. Results revealed that, in $80 \%$ of the cases, nudibranchs aligned their bodies towards the east. However, when the ambient field was rotated by $180^{\circ}$ (i.e., the GMF east became west and the south became north), nudibranchs lost their turning preference. Moreover, Popescu and Willows (1999) suggested that, after being moved away from their feeding area due to currents or predators, sea slugs could orient shoreward using geomagnetic cues. In addition, Tritonia tetraquetra offered the first opportunity to study the neural circuitry underlying magnetic orientation behaviour. Intracellular electrophysiological recordings indicated that some of its neuron pairs altered their electrical activity after geomagnetic rotations (Cain et al., 2006; Lohmann and Willows, 1991; Popescu and Willows, 1999; Wang et al., 2004, 2003).

In invertebrates, electric sensing of DC and AC low-frequency electric fields has only been reported in freshwater crayfish, with the behaviour of Cherax destructor and Procambarus clarkii (i.e., active behaviour with claws down, movements of the claws and 
antennae) significantly modified in response to DC electric fields of 3 to $7 \mathrm{mV} / \mathrm{m}$ and $A C$ fields (i.e., 4, 10, and $100 \mathrm{~Hz}$ ) and DC fields of $20 \mathrm{mV} / \mathrm{cm}$, respectively. Unfortunately, the authors failed to identify the specialised electroreceptors or the biological functions of the crayfish electric sense, as individuals responded to very high fields compared to the typical fields of biological relevance, from prey, predators, and conspecifics (Patullo and Macmillan, 2007; Steullet et al., 2007). Patullo and Macmillan (2010) also reported electro-sensitivity ( 0.30 to $0.45 \mathrm{mV} / \mathrm{cm}, 3$ to $20 \mathrm{~Hz}$ ), defined by a significant reduction in body motion in $C$. destructor and C. quadricarinatus and proposed that crayfish might use electric signals to monitor the presence of a biological item of interest (e.g., food) and subsequently use other sensory modalities to allow better information processing.

\section{Responses of marine invertebrates to artificial magnetic fields}

Whereas perception of the Earth's magnetic field by marine invertebrates is poorly documented, far fewer studies focus on their responses to artificial magnetic fields (e.g., produced by SPCs during their operation phase) (Taormina et al., 2018). As far as we know, no study has ever isolated the effects of anthropogenic electric fields from those of magnetic fields in marine invertebrate species. As such research is still in its infancy, studies assessing the effects of artificial magnetic fields have only been conducted at the individual scale. Hence, according to Boehlert and Gill (2010), these effects cannot be reported as impacts, since there is no evidence that such magnetic fields induce changes at the population or community level or in ecological processes. Below, we review field and laboratory studies investigating the effects of artificial magnetic fields on marine and freshwater invertebrates. We decided to classify studies according to species location relative to SPCS and the physiological and behavioural processes under investigation, rather than follow a phylogenetic classification, as the studies are largely unevenly distributed. Assumptions about the expected effects of magnetic fields on behaviour have been formulated by Isaacman and Daborn (2011) through a Pathways of Effect (PoE) model: these fields may lead to repulsion or attraction reactions, induce changes in movement patterns, and alter navigation and orientation in mobile species. Physiological studies are scarcer and focus on stress-related parameters, cellular and nuclear processes, and reproduction. We stress that most protocols involved the high-intensity fields that are expected in close vicinity to the 
cable (unlikely at the water sediment interface for buried cables) that were produced by a Helmholtz coil system (i.e., two magnetic coils that produce a region of a nearly uniform magnetic field at their centre).

Based on Bochert and Zettler (2004), the effects of magnetic fields on the survival rates of invertebrates are not of high concern and accordingly are not the subject of a detailed section. Indeed, no changes in the survival rates of North Sea prawn (Crangon crangon), two isopod species (Saduria entomon and Sphaeroma hookeri), round crab (Rhithropanopeus harrisii), or blue mussel (Mytilus edulis) were reported after long-term exposure to $3.7 \mathrm{mT}$ static fields. Stankevičiūtè et al. (2019) obtained similar results with ragworm (Hediste diversicolor) and Baltic clam (Limecola balthica) after 12 days under an alternating field (i.e., $50 \mathrm{~Hz}$, from 0.85 to $1.05 \mathrm{mT}$ ).

\subsection{Behavioural responses of the epifauna to artificial magnetic fields}

\subsubsection{Assessing attraction or repulsion towards artificial magnetic fields}

Several laboratory and field studies investigated the spatial distribution of invertebrates in response to magnetic fields (produced by a Helmholtz coil system or real SPCS) associated either with potential shelters (magnets) or with one area of a tank or cage. Behavioural responses were only observed in four crustacean species. Indeed, larger individuals of spiny lobster (Panulirus argus) selected control versus magnet-equipped dens (703.1 mT DC for $15 \mathrm{~min}$ ), potentially displaying signs of repulsion (Ernst and Lohmann, 2018). However, attraction for magnet-equipped shelters was observed in two separate experimental studies in the edible crab (Cancer pagurus) and the spiny cheek crayfish (Orconectes limosus, freshwater species) (2.8 mT DC for $7 \mathrm{~h}$ or $800 \mu \mathrm{T}$ DC for $24 \mathrm{~h}$, respectively) (Scott et al., 2018; Tanski et al., 2005). The side selection behaviour displayed by $C$. pagurus under control conditions disappeared when one side of the tank was exposed to a magnetic field ( 3 electromagnets, $2.8 \mathrm{mT}$ DC for $24 \mathrm{~h}$ ). The authors suggested that the magnetic field could stimulate shelter-seeking behaviour, thus preventing the crabs from settling in a specific side. Similarly, Corte Rosaria and Martin (2010) observed a maximal aggregation of Barytelphusa canicularis freshwater crabs close to a power supply source (50 $\mathrm{Hz}$, other values unavailable), from 60 to $90 \mathrm{~min}$ after its activation, which then decreased (until $150 \mathrm{~min}$ ) as the crabs slowly scattered and behaved as control individuals. 
The following studies did not report any attraction or repulsion behaviour towards an artificial magnetic field in eight crustacean species (distinct from those mentioned above), one echinoderm species, and two mollusc species. In a field experiment off the coast of Southern California, the spatial distribution in a cage of either red (Cancer productus) or yellow rock crab (Metacarcinus anthonyi) was not altered when located above an energised cable (46.2 $\mu \mathrm{T}$ to $80 \mu \mathrm{T}$ at $60 \mathrm{~Hz}$ AC, for $1 \mathrm{~h}$, cable features missing) versus an almost nonenergised cable $(0.2 \mu \mathrm{T}$ ) (Love et al., 2015). Similarly, the catchability of $C$. productus and the Dungeness crab (Metacarcinus magister) was unaffected by the presence of an operating cable at the entrance of a baited pot (cable 1: $35 \mathrm{kV}, 13.8$ to $116.8 \mu \mathrm{T}$ at $60 \mathrm{~Hz}$ AC; cable 2: $69 \mathrm{kV}, 24.6$ to $42.8 \mathrm{kV}$ at $60 \mathrm{~Hz}$ AC) (Love et al., 2017). Supporting these results, Bochert and Zettler (2006) found no changes in the spatial distribution of the North Sea prawn (Crangon crangon), the isopod (Saduria entomon), the round crab (Rhithropanopeus harrisii), and the common starfish (Asturia rubens) in response to the unilateral magnetic field exposure of their tank (2.8 mT DC for $1.5 \mathrm{~h}$ ). Likewise, neither the Dungeness crab (M. magister) nor the American lobster (Homarus americanus) modified their use of space after exposure to a magnetic field gradient (single Helmholtz coil located centrally and producing a maximal DC magnetic field of $1.01 \mathrm{mT}$, decaying to $0.05 \mathrm{mT}$ at both ends of the tank, over $24 \mathrm{~h}$ ) (Woodruff et al., 2013, 2012). In a similar design (i.e AC and DC magnetic field gradients with a maximal intensity of $200 \mu \mathrm{T}$ decaying to GMF values), juvenile European lobsters (Homarus gammarus) did not alter neither their exploratory behaviour (defined by mean velocity, total distance travelled and activity ratio) nor their shelter seeking behaviour (i.e time to find shelter, time spent in exposed vs control shelter) compared to control individuals (Taormina et al., 2020). The authors reached the same conlusions when testing (same procedure) the lobsters after one week of exposure to an homogeneous magnetic field of $225 \pm 5 \mu \mathrm{T} \mu \mathrm{T}$, either AC or DC. Finally, Cada et al. (2011) introduced individuals of the clam Corbicula fluminea and the snail Elimia clavaeformis (freshwater epigenean fauna) into a tank with two contrasting areas, one exposed to $36 \mathrm{mT}$ DC magnetic field generated by magnets and one control. They did not observe any magnetic field influence on the spatial distribution of these two freshwater molluscs over a $48 \mathrm{~h}$ period.

\subsubsection{Assessing the effects on movement patterns and activity rhythm}


Both laboratory and field studies found some effects of magnetic fields on the movement patterns and activity rhythm of one crustacean species. Hutchison et al. (2018) described the movement patterns of the American lobster (Homarus americanus) inside a wide enclosure located above an energised cable (HVDC buried at $2 \mathrm{~m}$ depth, maximum values: $330 \mathrm{MW}, 300 \mathrm{kV}, 1175 \mathrm{~A}$, for 12-24 h) generating magnetic fields ranging from approximately 99.2 to $116.6 \mu \mathrm{T}$. In this enclosure, lobsters spent more time in the centre and displayed more directional changes than those in the control enclosure (GMF of 51.3 $\mu \mathrm{T}$ ).

In contrast, Woodruff et al., 2013 found no significant effect of magnetic exposure on the activity rhythm (i.e., frequency of changes between stationary and active behaviours) of the Dungeness crab (M. magister) after $72 \mathrm{~h}$ of exposure to a magnetic field gradient (1100 $\mu \mathrm{T}$ DC decaying to approximately $330 \mu \mathrm{T}$ ). Similarly, Scott et al. (2018) did not detect any modification of the time spent in movement under a $3 \mathrm{mT}$ exposure $(7 \mathrm{~h})$ for juveniles of the edible crab (C. pagurus).

\subsubsection{Assessing the effects on migration process}

To our knowledge, only Tomanova and Vacha (2016) investigated the effect of magnetic fields on short-range migrations in invertebrates. They observed that, after a 1minute exposure to very weak radiofrequency electromagnetic fields ( 2 and $20 \mathrm{nT}$ at $1 \mathrm{MHz}$ AC), Gondogenia antartica amphipods became unable to orient in the direction of their natal beach in the manner of non-exposed individuals.

\subsection{Behavioural responses of the infauna}

\subsubsection{Assessing attraction or repulsion towards artificial magnetic fields}

Polychaetes, represented by the ragworm Hediste diversicolor, have been the only group of infauna studied from a behavioural perspective. Bochert and Zettler (2006) studied their spatial distribution with either exposed (2.8 $\mathrm{mT}$ DC produced by ring coils) or nonexposed sides of a tank. No difference was detected between the spatial patterns of the two treatments in the $22 \mathrm{~h}$ following the $1.5 \mathrm{~h}$ exposure duration. This result was also confirmed by the experiment of Jakubowska et al. (2019) with different magnetic fields (up to $1 \mathrm{mT} 50$ $\mathrm{Hz}, \mathrm{AC}$ ) over 8 days.

\subsubsection{Assessing the effect on burrowing and emerging behaviour}


The burrowing behaviour in many invertebrate species, assessed through burial depth and sediment reworking activity, is considered to be a very sensitive indicator of sediment toxicity or water-borne toxicant (Boyd et al., 2002). In the lab, Jakubowska et al. (2019) observed that larger amounts of tracer particles (i.e., fractionated dyed sand added to the sediment surface at the start of the experiment) were found deeper (below $3 \mathrm{~cm}$ ) after 8 days in the sediment of cores exposed to an alternating magnetic field $(1 \mathrm{mT}$ at $50 \mathrm{~Hz}$, Helmholtz coil system) compared to control cores, both containing $H$. diversicolor adults. This observation could not be explained by exposed individuals going deeper into the sediment, since they reached a maximal depth similar to control ragworms. According to the authors, one possible explanation could be an increase in the bioturbation activity of exposed polychaetes, leading to a stronger mixing of particles (e.g., more time spent in deeper sediment layers, more upward and downward migrations). This explanation is reinforced by the fact that control ragworms colonised mostly the upper sediment layers, whereas the magnetic field-exposed individuals were mostly found below such layers. Finally, the magnetic treatment did not modify the emerging response of polychaetes.

\subsection{Physiological responses of the epifauna to artificial magnetic fields}

Until now, only the work of Scott et al. (2018) and Bochert and Zettler (2006) described an integrative approach for assessing artificial magnetic field effects by coupling the measurements of physiological and behavioural parameters, with an emphasis on stressrelated parameters, physiological mechanisms involved in circadian rhythms, cellular division, reproduction, and development.

\subsubsection{Effects on stress-related parameters and circadian rhythm}

First, no changes have been reported in the oxygen consumption rate of adults of North Sea (Crangon crangon) and Baltic prawns (Palaemon squilla) and juveniles of edible crab (Cancer pagurus) during magnetic field treatments (prawns: $3.2 \mathrm{mT}$ DC or $50 \mathrm{~Hz}$ AC over $3 \mathrm{~h}$; edible crab: $2.8 \mathrm{mT}$ over 6 h) (Bochert and Zettler, 2006; Scott et al., 2018). However, for C. pagurus, the normal night-time increases in D-Lactate and D-Glucose concentrations in haemolymph were no longer observed in exposed juveniles (Scott et al., 2018). One possible explanation proposed by the authors could be linked to a pause in the secretion of melatonin, a neuropeptide involved in biological rhythms. They also investigated whether a 
1 high-strength magnetic field might cause an increase in haemocyanin concentrations, as in hypoxic conditions, and they found no significant effect.

\subsubsection{Effects on cellular division processes}

Cellular processes in Mediterranean mussel (Mytilus galloprovincialis) were disrupted after a short-term (i.e., 15 to $30 \mathrm{~min}$ ) magnetic field exposure (300-1000 $\mu \mathrm{T}$ at $50 \mathrm{~Hz} \mathrm{AC}$ ) (Malagoli et al., 2004, 2003; Ottaviani et al., 2002). Particularly, the authors reported that magnetic fields ranging from 300 to $1000 \mu$ T delay shape changes in immunocytes (i.e., a step in a phagocytosis reaction), suggesting alterations in the immune system (Ottaviani et al., 2002). However, subsequent experiments demonstrated the reversibility of the phenomenon with the activation of a 'stress pathway' (i.e., heat shock protein synthesis), clearly evident with a $400 \mu \mathrm{T}$ exposure but lacking with higher values (Malagoli et al., 2004, 2003).

\subsubsection{Effects on development and reproduction processes}

A high-strength magnetic field applied during sea urchins' (echinoderms group) (Strongylocentrotus purpuratus and Lytechinus pictus) fertilisation (permanent magnets: 0.1 $\mathrm{mT}$ at $60 \mathrm{~Hz} \mathrm{AC}$ for $23 \mathrm{~h}$ and $30 \mathrm{mT} \mathrm{DC}$ for $26 \mathrm{~h}$, respectively) delayed cell division in embryos (Levin and Ernst, 1997; Zimmerman et al., 1990). In addition, Levin and Ernst (1997) emphasised an increase in developmental abnormalities, but only in L. pictus (30 mT DC and $0.39 \mathrm{mT}$ at $60 \mathrm{~Hz} \mathrm{AC}$, for 48-94 h). However, a 93-day exposure (DC up to $3.7 \mathrm{mT}$ ) throughout the reproductive period of the blue mussel (Mytilus edulis) did not affect either its condition index or its gonad development index (Bochert and Zettler, 2004).

\subsection{Physiological responses of the infauna to artificial magnetic fields}

The recent laboratory study of Jakubowska et al. (2019) was conducted on marine ragworm (Hediste diversicolor) exposed to a magnetic field over an 8-day period (up to $1 \mathrm{mT}$ at $50 \mathrm{~Hz} \mathrm{AC}$ ). Whereas food consumption and respiration rates did not significantly change, the ammonia excretion rate significantly decreased for exposed worms compared to control worms. The authors suggested that $H$. diversicolor is unable to perceive high-strength magnetic fields as stressors, but they did not provide any explanatory hypothesis for this first report of one alteration of the excretion function. Similarly, Stankevičiūtè et al. (2019) 
1 showed an elevation in genotoxic effects in worm coelomocytes in response to an

2 alternating field (up to $1 \mathrm{mT}$ at $50 \mathrm{~Hz}$ AC, for 12 days). They also observed an induction or

3 increase in both genotoxic and cytotoxic effects in gill cells of the Baltic clam (L. balthica).

4

5

\section{Discussion}

\subsection{Main findings}

Over the past decade, the scientific literature on artificial magnetic fields and marine invertebrates' responses has improved markedly, although many uncertainties remain (see Table 2). There is a real lack of data for assessing the influence of artificial electric fields on invertebrates, which is partly attributable to the insufficient knowledge regarding their electric-sensing abilities. Nevertheless, as electromagnetic induction theory, commonly proposed for elasmobranch magneto-sensitivity, is newly discussed in other taxa (i.e. pigeons), this could stimulate the search for electroreceptors in marine invertebrate species.

Whereas the multi-species study (e.g., seven species of decapod and isopod crustaceans, bivalve molluscs) of Bochert and Zettler (2006) highlights that magnetic fields have a minor impact on the survival of adult stages, $75 \%$ of the studies reviewed here show significant effects on short-term physiological and behavioural responses. When reviewing the existing literature, we chose to make a clear distinction between the processes studied at the physiological and behavioural levels, since they were generally not considered together. In contrast to fish species (Formicki and Perkowski, 1998; Sedigh et al., 2019), in three distinct publications, none of the physiological parameters (e.g., oxygen consumption, respiration rate, food consumption) measured to detect stress responses were altered in the three crustaceans and the single polychaetes species studied (see Bochert and Zettler, 2006; Jakubowska et al., 2019; Scott et al., 2018). Then, Scott et al. (2018), working on Cancer pagurus crab, also suggested that magnetic fields might impair the secretion of D-Lactacte and D-Glucose enzymes, which are under the control of melatonin, a well-known hormone implied to act on biological rhythms of invertebrates (i.e., seasonal reproduction, moulting, and activity rhythms). This hypothesis has been largely addressed in vertebrates, but research findings were highly contradictory (details reviewed in Lewczuk et al., 2014). As yet, observations suggest no effects of long-term exposure to magnetic fields on the reproductive status of the blue mussel (Mytilus edulis) (Bochert and Zettler, 2006). 
1 Panagopoulos et al. (2002) suggested that AC fields are more detrimental to biological

elements than DC fields, which is confirmed since cellular alterations and developmental delays are mainly observed when adult and embryo stages of several taxa (echinoderms, bivalve molluscs) are submitted to alternating fields (Levin and Ernst, 1997; Malagoli et al., 2004, 2003; Ottaviani et al., 2002; Zimmerman et al., 1990).

With regard to behavioural responses, several laboratory and field experiments reported various species-specific behavioural changes in the best-studied crustacean taxa, (e.g., attraction, repulsion, effects on spatial distribution) (Corte Rosaria and Martin, 2010; Ernst and Lohmann, 2018; Hutchison et al., 2018; Scott et al., 2018; Tanski et al., 2005). For example, $50 \%$ of the papers provided support for an attraction towards magnetic fields in three crustacean species. Otherwise, $30 \%$ of the papers found no effects of magnetic fields while studying more taxonomic groups (i.e., crustaceans, echinoderms, molluscs, and polychaetes). One paper found repulsive behaviour (i.e., spiny lobster, P. argus) and another reported orientation disruption (i.e., Gondogenia antartica amphipods).

Caution should be exercised in the interpretation of such findings, since they do not necessarily reveal real biological impacts. To be considered impactful, a detected effect should have consequences at the population or community level (Boehlert and Gill, 2010). Because more than $75 \%$ of the works reviewed here relate to controlled experiments made at the individual level, it is therefore not possible to conclude if artificial magnetic fields effectively impact marine invertebrates' populations.

\subsection{What do we need to improve?}

\subsubsection{Choice of model species}

Up to now, research efforts have been made on very heterogeneous invertebrate taxa. Over the 24 species studied, $65 \%$ are crustaceans, mainly decapods, and for other taxa, often one single and redundant species is used among studies (e.g., Hediste diversicolor, polychaetes). Based on current knowledge, magnetic fields induce speciesspecific responses. Caution is thus needed when extrapolating the results obtained for a single species to an entire group of taxa. Presently, the main objective of the scientific community is to provide relevant study for ocean stakeholders. We thus suggest that species 
1 be classified and studied according to the duration and intensity of their exposure to magnetic and electric fields from cables. The first step in this approach should be to clearly categorise the exposure levels as a function of SPC features (e.g., AC or DC, high or medium voltage, length, current intensity, buried or laid on the sea bed) in order to define the spatial patterns of magnetic emissions (surface impacted, depth). For example, artificial magnetic fields cover larger areas with wind farm cabling (i.e., larger cable number) than with exportation or interconnection cables. In this context, it is crucial to link those elements with abiotic and biotic criteria to eventually define the associated fauna (Figure 2). Then, particular attention should be paid to the burrowing and sessile species (e.g. worms, bivalves), the first being exposed to the strongest emissions from buried cables, and the second being constrained to remain in the exposed area. Shelter-seeking species (lobsters, crabs) should also be a priority since they might find refuges in the cable protective structures. Other mobile species (e.g. cuttlefish, squids, sea slugs) are less at risk since their exposure is expected to be very short and occasional. Ubiquitous species should be preferentially selected for large-scale results extrapolation. So far, species selection did not result from a standardised procedure, and most work has been conducted on bio-indicator species commonly used to monitor marine environment pollution (e.g., Hediste diversicolor, Mytilus edulis, Crangon crangon) or commercial species (i.e., Cancer pagurus, Homarus americanus, Panulirus argus) (Bat et al., 2013; Garza Martinez, 2009; Quintaneiro et al., 2006). Such choices have not always been judicious, as for brackish species (Hediste diversicolor and Crangon crangon), since their main habitat (i.e., estuarine or mud flat) is usually excluded from cable laying due to high maritime traffic or ecological reasons (nursery). Another criterion for species selection should be the probability of sensing magnetic cues whose functional role is assumed to be used for orientation, navigation, and homing. Under such a hypothesis, magneto-sensitivity should be less developed in lowmobility species or those unable to undertake oriented movements (i.e., bivalve molluscs).

\subsubsection{Integrating artificial magnetic fields with SPC operating cycles and organism life- cycle stages}

One tricky aspect of laboratory experiments is setting the temporal patterns of magnetic field treatment to be consistent with those encountered on the field, both in terms of occurrence (single or multiple) and duration (occasional or chronic) (Gill et al., 2014; Orr, 
1 2016). For example, with tidal energy, electricity production is cyclical and the main variations are linked to neap and spring cycles. In contrast, with wind energy, electricity production is highly variable, although predictions are possible. For example, based on the wind seasonal cycle, there is higher energy production during winter and spring than during summer in Europe (Jourdier, 2015). Because electricity flows with interconnection SPCs are quite constant, exposed sedentary (infaunal bivalves), shelter-seeking (lobsters, crabs), or sessile species (mussels, barnacles, etc.) should receive a chronic and long-term exposure to magnetic fields. The potential associated effects are linked to the tolerance thresholds of species. If magnetic fields act at the physiological scale, individual fitness might be affected. In contrast, if tolerated, the magnetic signature of SPCs could also drive learning processes and eventually habituation processes in migrating species (Rankin et al., 2009).

For unburied cables, protective structures (3D structure and crevices) could also provide valuable habitats for egg-laying masses, whose embryonic development would be potentially influenced by magnetic fields. As mentioned above, artificial magnetic fields could induce life-stage specific responses (e.g., at the reproductive or embryonic stage). Still, studies on early-life stages of invertebrate (larvae, post-larvae, or juveniles) are extremely scarce. Most marine invertebrates (55\% to $85 \%$ ) display complex bentho-planktonic life cycles involving a quite long planktonic larval phase (from weeks to months), followed by a benthic phase as post-larval, juvenile and adult forms (Calado and Costa Leal, 2015). The sensitivity of invertebrates to magnetic field exposures should thus not only relate to the probability of being in proximity to SPCS and their current intensity but also to the developmental stage of a given species.

\subsubsection{Measuring and selecting relevant magnetic and electric field values}

Currently, accessing magnetic field measurements is very challenging, especially with real operating cables. As shown in Table 1, most data originate from theoretical calculations based on values used for cable peak performance (i.e., maximal intensity, power, voltage), which remain occasional under natural conditions. Consequently, most laboratory studies have been conducted with very high magnetic field values (i.e., millitesla range, $1 \mathrm{mT}=10^{-3}$ $\mu \mathrm{T}$ ), only reached in peak production and in close vicinity of the cable surface. Hence, these experimental designs do not reflect the conditions encountered by invertebrates within the 
1 benthic boundary layer. Variations in the tested magnetic field values could thus explain the often opposite results of laboratory versus field experiments. With the example of crustaceans tested in the laboratory, the high values of 0.8 to $2.8 \mathrm{mT}$ DC fields have induced attraction behaviours, whereas repulsive responses were observed in one sole study with a magnetic field of $703.1 \mathrm{mT}$, a largely irrelevant value for SPCs. Field studies did not show any significant effects of magnetic fields associated with real SPCs (60 Hz AC fields; see Table 2).

Among the few studies comparing in situ measurements with model prediction data, Hutchison et al. (2018) found both consistency between their average and extreme values as well as attenuation of the magnetic field with distance. For example, a predicted $2 \mu \mathrm{T}$ value (deviation from the GMF), corresponding to a distance of about $2 \mathrm{~m}$ above an HVDC cable operating at $345 \mathrm{~A}$, was close to the measured values (i.e., 2.8 to $3.8 \mu \mathrm{T}$ ). At the full power of $1175 \mathrm{~A}$, the maximal difference between the measured and predicted values was around 66 $\mu \mathrm{T}$. However, Otremba et al. (2019) reported values as high as $6 \mathrm{mT}$ in the close vicinity of DC transmission systems. In case of induced electric fields, Hutchison et al. (2018) reported values ranging from $0.02 \mathrm{mV} / \mathrm{m}$ to $0.25 \mathrm{mV} / \mathrm{m}$ above the cable (AC three-phase transmission at full power) (Table 1). To date, the magnetic and electric field intensity really experienced by marine fauna constitutes a very controversial topic with little accessible data. In addition, comparisons between the effects of static versus alternating fields are also lacking. For one $50 \mathrm{~Hz}$ AC cable, Hutchison et al. (2018) have detected AC field harmonics of higher frequencies whose potential interaction with marine organisms is unkown. Most laboratory studies have only assessed the effects of AC fields with 50 or $60 \mathrm{~Hz}$ frequencies, though the magneto- and electro-sensitivity of marine organisms might be frequency dependent. As bioelectric fields (produced by potential preys, predators and conspecifics) are usually less than $10 \mathrm{~Hz}$ (see Bedore and Kajiura, 2013), we expect marine organisms to be sensitive to this range of values. Testing one current intensity of $20 \mathrm{mV} / \mathrm{cm}$, Steullet et al. (2007) indeed reported evidence for electric sensing in crayfish (Procambarus clarkii) at $4 \mathrm{~Hz}, 10 \mathrm{~Hz}$ and $100 \mathrm{~Hz}$ frequencies, behavioural reactions being stronger at $4 \mathrm{~Hz}$. Moreover, Patullo and Macmillan (2010) observed an effect of frequency in Cherax destructor and Cherax quadricarinatus, that displayed behavioural changes at $3 \mathrm{~Hz}$ and $20 \mathrm{~Hz}$ frequencies but no at $40 \mathrm{~Hz}(0.3$ to $0.45 \mathrm{mV} / \mathrm{cm})$. 
In this context, there is a crucial need to define new standardised experimental designs to assess specific responses as a function of magnetic field features (AC or DC, intensity, frequency, etc.). These experiments should be conducted on a single species based on realistic in situ situations, as is done for dose-response ecotoxicological research. Actually, some studies do not accurately describe the details of the measurement operations (distance from the cable, cable type, and intensity), making comparisons of laboratory behavioural responses almost impossible and highly speculative.

\subsubsection{Improving experimental design to assess the effects of artificial magnetic fields}

As magnetoreception is assumed to be involved in orientation mechanisms, the responses of species might not occur instantly; as with natural conditions, the magnetic field sources are not expected to threaten the organism's survival. It is thus crucial to design experimental protocols with the view of detecting potential subtle behavioural changes. We thereafter detail the critical steps of an experimental design with an emphasis on some of the common pitfalls met in both laboratory and field studies, proper to the study of artificial magnetic fields. Tricky in controlled experiments, setting a suitable control treatment is even more difficult to do in large-scale field studies. As an example, some field studies are based on the comparison of one 'control' and one 'magnetic treatment'; these consist of one unenergised versus one energised cable, respectively, located under similar habitat and depth conditions. Because identical abiotic and biotic local conditions are quite impossible in the field, most in situ studies should integrate replicates of the different treatments (e.g., 3 distinct sites per control and also 3 per energised cable) as well as monitor the local environmental parameters (e.g., hydrodynamism, temperature, currents). If not, an observed attraction or repulsion (or a behavioural change) with exposure to an energised cable could in fact be a response to confounding factors such as visual, olfactory, acoustic, or hydrodynamic cues and may lead to wrong conclusions. Considering this perspective, we think that laboratory studies should be favoured to provide reliable results and reproducible conditions, especially as data on the potential magnetic sense of invertebrate species is lacking. However, the sensitivity and robustness of experimental studies are strongly dependent on the replication of treatments that integrate and limit the stochastic component (i.e., among-replicate variability, random events) (Hulbert, 1984). In many works, the results are not valid as there was no replication of treatments. Moreover, randomisation 
1 of treatment assignments must be carefully applied. For instance, tank sides exposed to a magnetic field should vary and be randomised through the experiment to guarantee a regular distribution of area-specific responses among the treatments (Milinski, 1997). As most studies use an imposing Helmholtz coil system, whether species might be influenced by the system itself should be monitored and may require an acclimation period prior to the experiment (i.e., without a magnetic field). Finally, because of the spatial constraints linked to the Helmholtz coil system, there is a temptation for scientists to include multiple samples per experimental unit (i.e., per tank) and subsequently treat them as independent samples. The main consequence of this is pseudoreplication with subsequent biased results (Hulbert, 1984; Milinski, 1997). That was not the case in Ernst and Lohmann (2018) or Jakubowska et al. (2019), who tested organisms individually or used several independent containers.

\section{Conclusion}

To conclude, renewable energy developers, regulators, scientists, engineers, and ocean stakeholders must work together to reach the common objective of clean renewable energy. The scientific community clearly needs better communication of magnetic and electric fields and in situ measurements in relation with the power production cycle, since such uncertainties are a significant barrier to research progress. Operators and developers should facilitate data collection to feed experiments that would be more relevant both at the ecological and technical level. Also, as induced electric fields are inherent to SPC operations, they should not be neglected but rather prioritised in future research projects. Future research should target a restricted number of species with the highest probability of exposure, both in term of duration (mobile versus sessile) and location (epifauna versus infauna). Further work is thus required to assess the effects of magnetic and electric fields on basic ecological functions, such as reproduction, feeding, or habitat selection, before any additional studies are conducted at the population level (distribution, demography).

\section{REFERENCES}

Ardelean, M., Minnebo, P., 2015. HVDC submarine power cables in the world: state-of-the-art knowledge (No. EUR 27527 EN). Joint Research Centre (JRC).

Arendse, M.C., Barendregt, A., 1981. Magnetic orientation in the semi-terrestrial amphipod, Orchestria cavimana, and its interrelationship with photo-orientation and water loss. Physiol. Entom. 6, 333-342. 
Arendse, M.C., Kruyswijk, C.J., 1981. Orientation of Talitrus saltator to magnetic fields. Neth. J. Sea Res. 15(1), 23-32. https://doi.org/10.1016/0077-7579(81)90003-X

Avens, L., Lohmann, K., 2004. Navigation and seasonal migratory orientation in juvenile sea turtles. J. Exp. Biol. 207, 1771-1778. https://doi.org/10.1242/jeb.00946

Ball, R.E., Oliver, M.K., Gill, A.B., 2016. Early life sensory ability-ventilatory responses of thornback ray embryos (Raja clavata) to predator-type electric fields. Dev. Neurobiol. 76(7), 721-729. https://doi.org/10.1002/dneu.22355

Baltazar-Soares, M., Eizaguirre, C., 2017. Animal navigation: The eel's magnetic guide to the Gulf Stream. Curr. Biol. 27(12), R604-R606. https://doi.org/10.1016/j.cub.2017.04.042

Bat, L., Sahin, F., Üstun, F., Baki, G., Öztekin, H.C., 2013. Heavy metals in edible tissues of the brown shrimp Crangon crangon (Linnaeus, 1758) from the Southern Black Sea (Turkey). J. Back Sea Mediterranean Environ. 19(1), 70-81.

Bedore, C.N., Kajiura, S.M., 2013. Bioelectric fields of marine organisms: voltage and frequency contributions to detectability by electroreceptive predators. Physiol. Biochem. Zool. 86(3), 298-311. https://doi.org/10.1086/669973

Bevelhimer, M., Cada, G., Scherelis, C., 2015. Effects of electromagnetic fields on behavior of largemouth bass and pallid sturgeon in an experimental pond setting (No. ORNL/TM2015/580). Oak Ridge National Laboratory (ORNL), Oak Ridge, TN (United States).

Bevelhimer, M.S., Cada, G.F., Fortner, A.M., Schweizer, P.E., Riemer, K., 2013. Behavioral responses of representative freshwater fish species to electromagnetic fields. Trans. Am. Fish. Soc. $142(3), 802-813$. https://doi.org/10.1080/00028487.2013.778901

Bochert, R., Zettler, M.L., 2006. Effect of electromagnetic fields on marine organisms, in: Koller, J., Koppel, J., Peters, W. (Eds.), Offshore Wind Energy. Springer, Berlin, Heidelberg (Germany), pp. 223-234.

Bochert, R., Zettler, M.L., 2004. Long-term exposure of several marine benthic animals to static magnetic fields. Bioelectromagnetics 25(7), 498-502. https://doi.org/10.1002/bem.20019

Boehlert, G., Gill, A., 2010. Environmental and ecological effects of ocean renewable energy development - A current synthesis. Oceanography 23(2), 68-81. https://doi.org/10.5670/oceanog.2010.46

Boles, L.C., Lohmann, K., 2003. True navigation and magnetic maps in spiny lobsters. Nature 421, 6063. https://doi.org/10.1038/nature01226

Boyd, W.A., Brewer, S.K., Williams, P.L., 2002. Altered behaviour of invertebrates living in polluted environments, in: Dell'Omo, G. (Ed.), Behavioural Ecotoxicology, Ecological and environmental toxicology series. John Wiley \& Sons, Inc., Hoboken, NJ (United States), p. 492.

Bullock, T.H., Hopkins, C.D., Popper, A.N., Fay, R.R. (Eds.), 2005. Electroreception, Handbook of Auditory Research. Springer, New York, NJ (United States).

Cada, G.F., Bevelhimer, M., Riemer, K.P., Turner, J.W., 2011. Effects on freshwater organisms of magnetic fields associated with hydrokinetic turbines FY 2010 Annual Progress Report (No. ORNL/TM-2011/244). Oak Ridge National Laboratory (ORNL), Oak Ridge, TN (United States).

Cadiou, H., McNaughton, P.A., 2010. Avian magnetite-based magnetoreception: a physiologist's perspective. J. F R. Soc. Interface 7(suppl 2), 193-205. https://doi.org/10.1098/rsif.2009.0423.focus

Cain, S.D., Wang, J.H., Lohmann, K., 2006. Immunochemical and electrophysiological analyses of magnetically responsive neurons in the mollusc Tritonia diomedea. J. Comp. Physiol. A 192(3), 
235-245.

https://doi.org/ 10.1007/s00359-005-0063-8

Calado, R., Costa Leal, M., 2015. Chapter One - Trophic Ecology of Benthic Marine Invertebrates with Bi-Phasic Life Cycles: What Are We Still Missing?, in: Curry, B. (Ed.), Advances in Marine Biology. Elsevier, pp. 1-70. https://doi.org/10.1016/bs.amb.2015.07.001

Carter, L., Burnett, D., Drew, S., Marle, G., Hagadorn, L., Bartlett-Ncneil, D., Irvine, N., 2009. Submarine cables and the oceans: connecting the world (No. 31). International Cable Protection Committee Ltd (ICPC), The United Nations Environment Programme World Conservation Monitoring centre (UNEP-WCMC).

CMACS, 2003. A baseline assessment of electromagnetic fields generated by offshore windfarm cables (No. COWRIE-EMF-01-2002). Centre for Marine and Coastal Studies (CMACS), Centre for Intelligent Monitoring Systems, Applied Ecology Research Group (ARU), Collaborative Offshore Wind Research into the Environment (COWRIE), Birkenhead, UK.

Collin, S.P., 2019. Electroreception in vertebrates and invertebrates, in: Reference Module in Life Sciences. Elsevier, pp. 120-131.

Copping, A., Sather, N., Hanna, L., Whiting, J., Zydlewska, G., Staines, G., Gill, A.B., Hutchison, I., O'Hagan, A., Simas, T., Bald, J., Sparling, C., Wood, J., Masden, E., 2016. ANNEX IV 2016 State of the Science Report - Environmental effects of marine renewable energy development around the world. Pacific Northwest National Laboratory (PNNL).

Corte Rosaria, J.C., Martin, E.R., 2010. Behavioral changes in freshwater crab, Barytelphusa cunicularis after exposure to low frequency electromagnetic fields. World J. Fish Mar. Sci. 2(6), 487-494.

CSA Ocean Sciences Inc. and Exponent, 2019. Evaluation of potential EMF effects on fish species of commercial or recreational fishing importance in Southern New England (No. BOEM-2019049). U.S. Dept. of the Interior, Bureau of Ocean Energy Management (BOEM), Sterling, VA (United States).

Czech-Damal, N.U., Dehnhardt, G., 2013. Passive electroreception in aquatic mammals. J. Comp. Physiol. A 199(6), 555-563. https://doi.org/10.1007/s00359-012-0780-8

Eder, S.H.K., Cadiou, H., Muhamad, A., McNaughton, P.A., Kirschvink, J.L., Winklhofer, M., 2012. Magnetic characterization of isolated candidate vertebrate magnetoreceptor cells. Proc. Natl. Acad. Sci. 109(30), 12022-12027. https://doi.org/10.1073/pnas.1205653109

Emma, B., 2016. A review of the evidence of electromagnetic field (Emf) effects on marine organisms. Res. Rev. J. Ecol. Environ. Sci. 4(4).

Ernst, D.A., Lohmann, K., 2018. Size-dependent avoidance of a strong magnetic anomaly in Caribbean spiny lobsters. J. Exp. Biol. 221(5), jeb172205. https://doi.org/10.1242/jeb.172205

Ernst, D.A., Lohmann, K., 2016. Effect of magnetic pulses on Caribbean spiny lobsters: implications for magnetoreception. J. Exp. Biol. 219(Pt 12), 1827-1832. https://doi.org/10.1242/jeb.136036

Exponent Inc., 2013. Virginia offshore wind technology advancement project magnetic fields from submarine cables (No. 1206527.000 - 7629). Exponent, Inc. Bowie, MD, (United States).

Faraday, M. 1832. Experimental researches in electricity. Phil. Trans. R. Soc. Lond. 122, 125-162. https://doi.org/10.1098/rstl.1832.0006

Fey, D.P., Greszkiewicz, M., Otremba, Z., Andrulewicz, E., 2019a. Effect of static magnetic field on the hatching success, growth, mortality, and yolk-sac absorption of larval Northern pike Esox lucius. Sci. Total Environ. 647, 1239-1244. https://doi.org/10.1016/j.scitotenv.2018.07.427

Fey, Dariusz P., Jakubowska, M., Greszkiewicz, M., Andrulewicz, E., Otremba, Z., Urban-Malinga, B., 2019b. Are magnetic and electromagnetic fields of anthropogenic origin potential threats to 
early life stages of fish? Aquat. Toxicol. 209, 150-158.

https://doi.org/10.1016/j.aquatox.2019.01.023

Fischer, C., Slater, M., 2010. Electromagnetic Field Study. Effects of electromagnetic fields on marine species: A literature review (No. 0905-00-001). Oregon Wave Energy Trust, Oregon, (United States).

Formicki, K., Perkowski, T., 1998. The effect of a magnetic field on the gas exchange in rainbow trout Oncorhynchus mykiss embryos (Salmonidae). Ital. J. Zool. 65(sup1), 475-477. https://doi.org/10.1080/11250009809386869

Garza Martínez, P., 2009. Mytilus edulis as bioindicator for coastal zone environmental assessment: a study of Kosterhavets marine national park (Master thesis not published), Royal Institute of technology, Stockholm.

Gill, A.B., Gloyne-Philips, I., Sigray, P., 2014. Marine renewable energy, electromagnetic (EM) fields and EM-sensitive animals, in: Shields, M.A., Payne, A.I.L. (Eds.), Marine renewable energy technology and environmental interactions, Humanity and the Sea. Springer, Netherlands, Dordrecht. https://doi.org/10.1007/978-94-017-8002-5_6

Gill, A.B., Huang, Y., Gloyne-Philips, I., Metcalfe, J.D., Quayle, V., Spencer, J., Wearmouth, V., 2009. COWRIE 2.0 Electromagnetic Fields (EMF) Phase 2. EMF-sensitive fish response to EM emissions from sub-sea, electricity cables of the type used by the offshore renewable energy industry (No. COWRIE-EMF-1-06). Collaborative Offshore Wind Research into the Environment (COWRIE), Newbury, (UK).

Heilig, B., Beggan, C., János, L., 2018. Natural sources of geomagnetic field variations (No. CERN-ACC2018-0033). European Organization for nuclear research (CERN).

Herrnking, W.F., McLean, R., 1971. Field studies of homing, mass emigration, and orientation in the spiny lobster, Panulirus argus. Ann. N. Y. Acad. Sci. 188(1), 359-376. https://doi.org/10.1111/j.1749-6632.1971.tb13109.x

Hore, P.J., Mouritsen, H., 2016. The radical-pair mechanism of magnetoreception. Annu. Rev. Biophys. 45, 299-344. https://doi.org/10.1146/annurev-biophys-032116-094545

Hulbert, S., 1984. Pseudoreplication and the design of ecological field experiments. Ecol. Monogr. $54(2), 187-211$. https://doi.org/10.2307/1942661

Hutchison, Zoe, Sigray, P., He, H., Gill, A., King, J., Gibson, C., 2018. Electromagnetic field (EMF) impacts on elasmobranch (shark, rays, and skates) and American lobster movement and migration from direct current cables (No. BOEM 2018-003). Bureau of Ocean Energy Management (BOEM), Narragansett, RI, (United States).

Isaacman, L., Daborn, G., 2011. Pathways of effects for offshore renewable energy in Canada (No. 102). Acadia Centre for Estuarine Research (ACER), Wolfville, NS, Canada.

Isaacman, L., Lee, K., 2009. Current state of knowledge on the environmental impacts of tidal and wave energy technology in Canada (No. 2009/077). Centre for Offshore Oil, Gas and Energy Research (COOGER), Dartmouth, Nova Scotia.

Jakubowska, M., Urban-Malinga, B., Otremba, Z., Andrulewicz, E., 2019. Effect of low frequency electromagnetic field on the behavior and bioenergetics of the polychaete Hediste diversicolor. Mar. Environ. Res. 150, 104766. https://doi.org/10.1016/j.marenvres.2019.104766

Johansson, S.G., Liljestrand, L., Krogh, F., Karlstrand, J., Hanson, J., 2005. AC Cable solutions for Offshore Wind Energy. Presented at the Copenhagen Offshore Wind Conference, Copenhagen, pp. 1-10.

Johnsen, S., Lohmann, K.J., 2008. Magnetoreception in animals. Physics Today 61(3), 29. https://doi.org/10.1063/1.2897947

Jourdier, B., 2015. Ressource éolienne en France métropolitaine : méthodes d'évaluation du potentiel, variabilité et tendances (Climatologie). Ecole Doctorale Polytechnique. 
Kalmijn, A., J. 1982. Electric and magnetic field detection in elasmobranch fishes. Science 218(4575), 916-918. https://doi.org/10.1126/science.7134985

Kalmijn, A., J. 1978. Experimental evidence of geomagnetic orientation in elasmobranch fishes, in: Schmidt-Koenig, K., Keeton, W.T. (Eds.), Animal Migration, Navigation, and Homing: Symposium Held at the University of Tübingen, August 17-20, 1977, Proceedings in Life Sciences. Springer, Berlin, Heidelberg (Germany).

Kavet R, Wyman MT, Klimley AP, 2016. Modeling magnetic fields from a DC power cable buried beneath San Francisco bay based on empirical measurements. PLoS ONE 11(2), e0148543. https://doi.org/10.1371/journal.pone.0148543

Klimley, A.P., Wyman, M.T., Kavet, R., 2016. Assessment of potential impact of electromagnetic fields from undersea cable on migratory fish behaviour (No. FINAL REPORT, DOE-EPRI-EE0006382 OCS Study BOEM 2016-041). Electric Power Research Institute (EPRI), Palo Alto, CA (United States). https://doi.org/10.2172/1406896

Kremers, D., López Marulanda, J., Hausberger, M., Lemasson, A., 2014. Behavioural evidence of magnetoreception in dolphins: detection of experimental magnetic fields.

Naturwissenschaften 101, 907-911. https://doi.org/10.1007/s00114-014-1231-x

Levin, M., Ernst, S.G., 1997. Applied DC magnetic fields cause alterations in the time of cell divisions and developmental abnormalities in early sea-urchin embryos. Bioelectromagnetics 18(3), 255-63. https://doi.org/10.1002/(SICI)1521-186X(1997)18:3<255::AID-BEM9>3.0.CO;2-1

Lewczuk, B., Redlarski, G., Zak, A., Ziolkowska, N, Przybylska-Gornowicz, B., Krawczuk, M., 2014. Influence of electric, magnetic, and electromagnetic fields on the circadian system: current stage of knowledge. Biomed Research International, 2014, 13. https://doi.org/10.1155/2014/169459

Light, P., Salmon, M., Lohmann, K., 1993. Geomagnetic orientation of Loggerhead sea turtles: evidence for inclination compass. J. Exp. Biol. 182, 1-10.

Lohmann, K.J., Ernst, D.A., 2014. The geomagnetic sense of crustaceans and its use in orientation and navigation, in: Derby, C., Thiel, M. (Eds.), Nervous systems and control of behavior. Oxford University Press.

Lohmann, K.J., Putman, N.F., Lohmann, C.M., 2012. The magnetic map of hatchling loggerhead sea turtles. Curr. Opin. Neurobiol. 22(2), 336-342. https://doi.org/10.1016/j.conb.2011.11.005

Lohmann, K.J., Lohmann, C.M.F., Putman, N.F., 2007. Magnetic maps in animals: nature's GPS. J. Exp. Biol. 210, 3697-3705. https://doi.org/10.1242/jeb.001313

Lohmann, K.J., Cain, S.D., Dodge, S.A., Lohmann, C.M.F., 2001. Regional magnetic fields as navigational markers for sea turtles. Sci. New Ser. 294(5541), 364-366. https://doi.org/10.1126/science.1064557

Lohmann, K.J., Pentcheff, N.D., Nevitt, G.A., Stetten, G.D., Zimmer-Faust, R.K., Jarrard, H.E., Boles, L.C., 1995. Magnetic orientation of spiny lobsters in the ocean: experiments with undersea coil systems. J. Exp. Biol. 198, 2041-2048.

Lohmann, K.J., Lohmann, C.M.F., 1994. Detection of magnetic inclination angle by sea turtles: a possible mechanism for determining latitude. J. Exp. Biol. 194, 23-32.

Lohmann, K.J., 1991. Magnetic orientation by hatchling Loggerhead Sea turtles (Caretta caretta). J. Exp. Biol. 155, 37-49.

Lohmann, K.J., Willows, A.O., 1991. An identifiable molluscan neuron responds to changes in Earthstrength magnetic fields. J. Exp. Biol. 161(1), 1-24.

Lohmann, K.J., Willows, A.O.D., 1987. Lunar-modulated geomagnetic orientation by a marine mollusk. Science 235(4786), 331-334. 
https://doi.org/10.1126/science.3798115

Love, M.S., Nishimoto, M.M., Clark, S., McCrea, M., Scarborough, B., 2017. Assessing potential impacts of energized submarine power cables on crab harvests. Cont. Shelf Res. 151(1), 2329. https://doi.org/10.1016/j.csr.2017.10.002

Love, M.S., Nishimoto, M.M., Clark, S., Scarborough, B., 2015. Identical response of caged rock crabs (Genera Metacarcinus and Cancer) to energized and unenergized undersea power cables in Southern California, USA. Bull. South. Calif. Acad. Sci. 114(1), 33-41. https://doi.org/10.3160/0038-3872-114.1.33

Lowenstam, H.A., 1962. Magnetite in denticle capping in recent chitons (Polyplacophora). Geol. Soc. Am. Bull. 73(4), 435-438. https://doi.org/10.1130/0016-7606(1962)73[435:MIDCIR]2.0.CO;2

Malagoli, D., Gobba, F., Ottaviani, E., 2004. $50 \mathrm{~Hz}$ magnetic fields activate mussel immunocyte p38 MAP kinase and induce HSP70 and 90. Comp. Biochem. Physiol. Part C Tox. Pharm. 137(1), 75-79. https://doi.org/10.1016/j.cca.2003.11.007

Malagoli, D., Gobba, F., Ottaviani, E., 2003. Effects of 50-Hz magnetic fields on the signalling pathways of $\mathrm{FMLP}$-induced shape changes in invertebrate immunocytes: the activation of an alternative "'stress pathway." Biochim. Biophys. Acta 1620(1-3), 185-190. https://doi.org/10.1016/S0304-4165(02)00531-7

Malkemper, E. P., Kagerbauer, D., Ushakova, L., Nimpf, S., Pichler, P., Treiber, C. D., de Jonge, M., Shaw, J., Keays, D.A., 2019. No evidence for a magnetite-based magnetoreceptor in the lagena of pigeons. Current Biology, 29(1), R14-R15. https://doi.org/10.1016/j.cub.2018.11.032

Meißner, K., Schabelon, H., Bellebaum, J., Sordyl, H., 2006. Impacts of submarine cables on the marine environment - A literature review. Institute of Applied Ecology (IfAO). Neu Broderstorf (Germany).

Meyer, C.G., Holland, K.N., Papastamatiou, Y.P., 2005. Sharks can detect changes in the geomagnetic field. J. R. Soc. Interface 2, 129-130. https://doi.org/10.1098/rsif.2004.0021

Michel, J., Dunagan, H., Boring, C., Healy, E., Evans, W., Dean, J.M., McGillis, A., Hain, J., 2007. Worldwide synthesis and analysis of existing information regarding environmental effects of alternative energy uses on the outer continental shelf (No. MMS 2007-038). U.S. Department of the Interior, Minerals Management Service (MMS), Herndon, VA (United States).

Milinski, M., 1997. How to avoid seven deadly sins in the study of behavior. Adv. Study Behav. 26, $159-180$. https://doi.org/10.1016/S0065-3454(08)60379-4

Naisbett-Jones, L.C., Putman, N.F., Stephenson, J.F., Ladak, S., Young, K.A., 2017. A magnetic map leads juvenile European eels to the Gulf Stream. Curr. Biol. 27(8), 1236-1240. https://doi.org/10.1016/j.cub.2017.03.015

Natan, E., Vortman, Y., 2017. The symbiotic magnetic-sensing hypothesis: do magnetotactic bacteria underlie the magnetic sensing capability of animals? Mov. Ecol. 5, 22. https://doi.org/10.1186/s40462-017-0113-1

Natural power, 2015. Etude d'impact du parc éolien en mer de Saint-Nazaire et de son raccordement au réseau électrique- Fasicule 0 - Résumé non technique. Parc éolien en mer de SaintNazaire, Réseau Transport Electricité de France (Rte), Natural power, France.

Nevitt, G.A., Pentcheff, N.D., Lohmann, K., Zimmer-Faust, R.K., 1995. Evidence for hydrodynamic orientation by spiny lobsters in a patch reef environment. J. Exp. Biol. 198(10), 2049-2054.

Nimpf, S., Nordmann, G.C., Kagerbauer, D., Malkemper, E.P., Landler, L., Papadaki-Anastasopoulou, A., Ushakova, L., Wenninger-Weinzierl, A., Novatchkova, M., Vincent, P., Lendl, T., Colombini, M., Mason, M.J., Keays, D.A., 2019. A putative mechanism for magnetoreception by electromagnetic induction in the pigeon inner ear. Curr. Biol. 29(23), 4052-4059. 
https://doi.org/10.1016/j.cub.2019.09.048

Nordmann, G.C., Hochstoeger, T., Keays, D.A., 2017. Magnetoreception - A sense without a receptor. PLoS Biol 15(10): e2003234. https://doi.org/10.1371/journal.pbio.2003234

Öhman, M.C., Sigray, P., Westerberg, H., 2007. Offshore windmills and the effects of electromagnetic fields on fish. Ambio 36(8), 630-633. https://doi.org/10.1579/0044-7447(2007)36[630:OWATEO]2.0.CO;2

Olsen, N., Hulot, G., Sabaka, T., 2010. Sources of the geomagnetic field and the modern data that enable their investigation, in: Freeden, W., Nashed, Z.M., Sonar, T. (Eds.), Handbook of geomathematics. Springer, Berlin, Heidelberg (Germany). https://doi.org/10.1007/978-3-642-01546-5_5

Orr, M., 2016. The potential impacts of submarine power cables on benthic elasmobranchs. (Thesis not published). University of Auckland, Auckland. http://hdl.handle.net/2292/30773

Otremba, Z., Jakubowska, M., Urban-Malinga, B., Andrulewicz, E., 2019. Potential effects of electrical energy transmission - the case study from the Polish Marine Areas (southern Baltic Sea). Oceanol. Hydrobiol. Stud. 48(2), 196-208. https://doi.org/10.1515/ohs-2019-0018

Ottaviani, E., Malagoli, D., Ferrari, A., Tagliazucchi, D., Conte, A., Gobba, F., 2002. 50 Hz Magnetic fields of varying flux intensity affect cell shape changes in invertebrate immunocytes: the Role of potassium ion channels. Bioelectromagnetics 23(4), 292-297. https://doi.org/10.1002/bem.10021

Panagopoulos, D.J., Karabarbounis, A., Margaritis, L.H., 2002. Mechanism for action of electromagnetic fields on cells. Biochem. Biophys. Res. Commun. 298(1), 95-102. https://doi.org/10.1016/s0006-291x(02)02393-8

Patullo, B.W., Macmillan, D.L., 2010. Making sense of electrical sense in crayfish. J. Exp. Biol. 213, 651-657. https://doi.org/10.1242/jeb.039073

Patullo, B.W., Macmillan, D.L., 2007. Crayfish respond to electrical fields. Curr. Biol. 17(3), 83-84. https://doi.org/10.1016/j.cub.2006.11.048

Popescu, I.R., Willows, A.O.D., 1999. Sources of magnetic sensory input to identified neurons active during crawling in the marine mollusc Tritonia diomedea. J. Exp. Biol. 202(21), 3029-3036.

Prather, C.M., Pelini, S.L., Laws, A., Rivest, E., Woltz, M., Bloch, C.P., Del Toro, I., Ho, C.-K., Kominoski, J., Newbold, T.A.S., Parsons, S., Joern, A., 2013. Invertebrates, ecosystem services and climate change. Biol. Rev. 88(2), 327-348.

https://doi.org/10.1111/brv.12002

Putman, N.F., Endres, C.S., Lohmann, C.M.F., Lohmann, K.J., 2011. Longitude perception and bicoordinate magnetic maps in sea turtles. Curr. Biol. 21(6), 463-466. https://doi.org/10.1016/j.cub.2011.01.057

Putman, Nathan F., Meinke, A.M., Noakes, D.L.G., 2014a. Rearing in a distorted magnetic field disrupts the 'map sense' of juvenile steelhead trout. Biol. Lett. 10(6), 20140169. https://doi.org/10.1098/rsbl.2014.0169

Putman, Nathan F., Scanlan, M.M., Billman, E.J., O’Neil, J.P., Couture, R.B., Quinn, T.P., Lohmann, K.J., Noakes, D.L.G., 2014b. An inherited magnetic map guides ocean navigation in juvenile pacific salmon. Curr. Biol. 24(4), 446-450. https://doi.org/10.1016/j.cub.2014.01.017

Quinn, T.P., Brannon, E.L., 1982. The use of celestial and magnetic cues by orienting sockeye salmon smolts. J. Comp. Physiol. A 147, 547-552. https://doi.org/10.1007/BF00612020

Quinn, T.P., 1980. Evidence for celestial and magnetic compass orientation in lake migrating sockeye salmon fry. J. Comp. Physiol. 137, 243-248. https://doi.org/10.1007/BF00657119 
Quintaneiro, C., Monteiro, M., Soares, A.M.V.M., Nogueira, A.J.A., Morgado, F., Guilhermino, L., 2006. Environmental pollution and natural populations: A biomarkers case study from the Iberian Atlantic coast. Mar. Pollut. Bull. 52(11), 1406-1413. https://doi.org/10.1016/j.marpolbul.2006.04.002

Rankin, C., Abrams, T., Barry, R., Bhatnagar, S., Clayton, D., Colombo, J., Coppola, G., Geyer, M., Glanzman, D.L., Marsland, S., McSweeney, F., Wilson, D.A., Wu, C., Thompson, R.F., 2009. Habituation revisited: An updated and revised description of the behavioral characteristics of habituation. Neurobiol. Learn. Mem. 92(2), 135-138. https://doi.org/10.1016/j.nlm.2008.09.012

Ritz, T., Ahmad, M., Mouritsen, H., Wiltschko, R., Wiltschko, W., 2010. Photoreceptor-based magnetoreception: optimal design of receptor molecules, cells, and neuronal processing. J. R. Soc. Interface 7.

Ritz, T., Adem, S., Schulten, K., 2000. A model for photoreceptor-based magnetoreception in birds. Biophys. J. 78(2), 707-718. https://doi.org/10.1016/S0006-3495(00)76629-X

Rte, 2019. Les interconnexions, in : Schéma décennal de développement du réseau - Document de référence. Réseau Transport Electricité de France (Rte). Paris, France.

Schulten, K., Swenberg, C.E., Weller, A., 1978. A biomagnetic sensory mechanism based on magnetic field modulated coherent electron spin motion. Z. Für Phys. Chem. 111(1), 1-5. https://doi.org/10.1524/zpch.1978.111.1.001

Scott, K., Harsanyi, P., Lyndon, A.R., 2018. Understanding the effects of electromagnetic field emissions from marine renewable energy devices (MREDs) on the commercially important edible crab, Cancer pagurus ( L .). Mar. Pollut. Bull. 131(Part A), 580-588. https://doi.org/10.1016/j.marpolbul.2018.04.062

Sedigh, E., Heidari, B., Roozati, A., Valipour, A., 2019. The effect of different intensities of static magnetic field on stress and selected reproductive indices of the zebrafish (Danio rerio) during acute and subacute exposure. Bull. Environ. Contam. Toxicol. 102(2), 204-209. https://doi.org/10.1007/s00128-018-02538-1

Shaw, J., Boyd, A., House, M., Woodward, R., Mathes, F., Cowin, G., Saunders, M., Baer, B., 2015. Magnetic particle-mediated magnetoreception. J. R. Soc. Interface 12, 20150499. https://doi.org/10.1098/rsif.2015.0499

Silva, J.M., Zaffanella, L.E., Daigle, J.P., 2006. EMF Study. Long Island Power Authority (LIPA), Offshore Wind Project. 74 pp.

Snelgrove, P.V.R., 1997. The importance of marine sediment biodiversity in ecosystem processes. Ambio 26(8), 578-583. https://www.jstor.org/stable/4314672

Stankevičiūtè, M., Jakubowska, M., Pažusienè, J., Makaras, T., Otremba, Z., Urban-Malinga, B., Fey, D.P., Greszkiewicz, M., Sauliutè, G., Baršienè, J., Andrulewicz, E., 2019. Genotoxic and cytotoxic effects of $50 \mathrm{~Hz} 1 \mathrm{mT}$ electromagnetic field on larval rainbow trout (Oncorhynchus mykiss), Baltic clam (Limecola balthica) and common ragworm (Hediste diversicolor). Aquat. Toxicol. 208, 109-117. https://doi.org/10.1016/j.aquatox.2018.12.023

Steullet, P., Edwards, D.H., Derby, C.D., 2007. An electric sense in crayfish? Biol. Bull. 213(1), 16-20. https://doi.org/10.2307/25066614

Sun, X., Huang, D., Wu, G., 2012. The current state of offshore wind energy technology development. En. 41(1), 298-312. https://doi.org/10.1016/j.energy.2012.02.054

Tanski, A., Formicki, K., Sadowski, M., Winnicki, A., 2005. Sheltering behaviour of spinycheek crayfish (Orconectes limosus) in the presence of an artificial magnetic field. Bull. Fr. Pêche Piscic. 376377, 787-793. https://doi.org/10.1051/kmae:2005033 
Taormina, B., Di Poi, C., Agnalt, A.-L., Carlier, A., Desroy, N., Escobar-Lux, R.H., D’Eu, J., Freytet, F., Durif, C.M.F., 2020. Impact of magnetic fields generated by AC/DC submarine power cables on the behavior of juvenile European lobster (Homarus gammarus). Aquat. Toxicol. 220, 105401. https://doi.org/10.1016/j.aquatox.2019.105401

Taormina, B., Bald, J., Want, A., Thouzeau, G., Lejart, M., Desroy, N., Carlier, A., 2018. A review of potential impacts of submarine power cables on the marine environment : Knowledge gaps, recommendations and future directions. Renew. Sustain. Energy Rev. 96, 380-391. https://doi.org/10.1016/j.rser.2018.07.026

Tomanova, K., Vacha, M., 2016. The magnetic orientation of the Antarctic amphipod Gondogeneia antarctica is cancelled by very weak radiofrequency fields. Co. Biol. 219(Pt 1), 1717-1724. https://doi.org/10.1242/jeb.132878

Tricas, T., Gill, A., 2011. Effects of EMFs from undersea power cables on elasmobranchs and other marine species (No. OCS Study BOEMRE 2011-09). U.S. Department of the Interior, Bureau of Ocean Energy Management (BOEM), regulation, and Enforcement. Pacific OCS Region, Camarillo, CA (United States).

Tricas, T.C., Sisneros, J.A., 2004. Ecological functions and adaptations of the elasmobranch electrosense, in: von der Emde, G., Mogdans, J., Kapoor, B.G. (Eds.), The Senses of Fish. Springer, Dordrecht (Netherlands), pp. 308-329. https://doi.org/10.1007/978-94-007-1060-3_14

Tyler, R. H., Maus, S.,Lühr, H., 2003. Satellite observations of magnetic fields due to ocean tidal flow. Science. 299(5604), 239-241. https://doi.org/10.1126/science.1078074

Ugolini, A., 2006. Equatorial sandhoppers use body scans to detect the earth's magnetic field. J. Comp. Physiol. A 192(1), 45-49. https://doi.org/10.1007/s00359-005-0046-9

Ugolini, A., 2002. The orientation of equatorial sandhoppers during the zenithal culmination of the sun. Ethol. Ecol. Evol. 14(3), 269-273. https://doi.org/10.1080/08927014.2002.9522745

Ugolini, A., Pezzani, A., 1995. Magnetic compass and learning of the $Y$-axis (sea-land) direction in the marine isopod Idotea baltica basteri. Anim. Behav. 50(2), 295-300. https://doi.org/10.1006/anbe.1995.0245

Ugolini, A., Pardi, L., 1992. Equatorial sandhoppers do not have a good clock. Naturwissenschaften 79, 279-281. https://doi.org/10.1007/BF01175398

Vacha, M., 2017. Magnetoreception of invertebrates, in: Byrne, J. (ed), The Oxford Handbook of Invertebrate Neurobiology. https://doi.org/10.1093/oxfordhb/9780190456757.013.16

Walker, M.M., Diebel, C.E., Kirschvink, J.L., 2003. Detection and Use of the Earth's Magnetic Field by Aquatic Vertebrates, in: Collin, S.P., Marshall, N.J. (Eds.), Sensory Processing in Aquatic Environments. Springer, New York, NJ (United States), pp. 53-74. https://doi.org/10.1007/978-0-387-22628-6_3

Walker, M.M., 1984. Learned magnetic field discrimination in yellowfin tuna, Thunnus albacares. J. Comp. Physiol. A 155(5), 673-679. https://doi.org/10.1007/BF00610853

Walton, A.S., Herrnkind, W.F., 1977. Hydrodynamic orientation of spiny lobster, Panulirus argus (Crustacea: Palinuridae): wave surge and unidirectional currents. Meml. Univ. Nfld. Mar. Sci. Res Lab Tech Rep 20, 184-211.

Wang, J.H., Cain, S.D., Lohmann, K., 2004. Identifiable neurons inhibited by Earth-strength magnetic stimuli in the mollusc Tritonia diomedea. J. Exp. Biol. 207(Pt 6), 1043-1049.

Wang, J.H., Cain, S.D., Lohmann, K., 2003. Identification of magnetically responsive neurons in the marine mollusc Tritonia diomedea. J. Exp. Biol. 206(Pt 2), 381-388. 
Wei, Q., Wu, B., Xu, D., Zargari, N.R., 2017. Overview of offshore wind farm configurations. IOP Conf. Ser. Earth Environ. Sci. 93. https://doi.org/10.1088/1755-1315/93/1/012009

Westerberg, H., Lagenfelt, I., 2008. Sub-sea power cables and the migration behaviour of the European eel. Fish. Manag. Ecol. 15(5-6), 369-375. https://doi.org/10.1111/j.1365-2400.2008.00630.x

Wiltschko, R., Wiltschko, W., 2019. Magnetoreception in birds. J. R. Soc. Interface 16, 20190295. https://doi.org/10.1098/rsif.2019.0295

Wiltschko, W., Wiltschko, R., 2005. Magnetic orientation and magnetoreception in birds and other animals. J. Comp. Physiol. A 191, 675-693. https://doi.org/10.1007/s00359-005-0627-7

Wiltschko, R., 1995. Magnetic Orientation in Animals. Zoophysiology. Springer Science \& Business Media, Berlin, Heidelberg (Germany), $297 \mathrm{p}$. https://doi.org/10.1007/978-3-642-79749-1

Winklhofer, M., Kirschvink, J.L., 2010. A quantitative assessment of torque-transducer models for magnetoreception. J. R. Soc. Interface 7, 273-289. https://doi.org/10.1098/rsif.2009.0435.focus

Woodruff, D.L., Cullinan, V.I., Copping, A., Marshall, K.E., 2013. Effects of electromagnetic fields on fish and invertebrates Task 2.1.3: Effects on aquatic organisms Fiscal Year 2012 Progress report (No. PNNL-22154). Pacific Northwest National Laboratory, Richland, Washington (United States).

Woodruff, D.L., Schultz, I.R., Marshall, K.E., 2012. Effects of Electromagnetic Fields on Fish and Invertebrates. Task 2.1.3: Effects on Aquatic Organisms. Fiscal Year 2011 Progress report (No. PNNL-20813). Pacific Northwest National Laboratory (PNNL), Richland, Washington (United States).

Worster, S., Mouritsen, H., Hore, P.J., 2017. A light-dependent magnetoreception mechanism insensitive to light intensity and polarization. J. R. Soc. Interface 14, 20170405. https://doi.org/10.1098/rsif.2017.0405

Worzyk, T., 2009. Submarine power cables: Design, installation, repair, environmental aspects. Power systems. Springer, Berlin, Heidelberg (Germany), 296 p. https://doi.org/10.1007/978-3-642-01270-9 Hardcover ISBN

Wyman, M.T., Klimley, A.P., Battleson, R.D., Agosta, T.V., Chapman, E.D., Haverkamp, P.J., Pagel, M.D., Kavet, R., 2018. Behavioral responses by migrating juvenile salmonids to a subsea highvoltage DC power cable. Mar. Biol. 165, 134. https://doi.org/10.1007/s00227-018-3385-0

Zimmerman, S., Zimmerman, A.M., Winters, W.D., Cameron, I.L., 1990. Influence of 60-Hz magnetic fields on sea urchin development. Bioelectromagnetics 11(1), 37-45. https://doi.org/10.1002/bem.2250110106 
Table 1. Magnetic induction of various power transmission systems obtained both by calculation (in bold) and field measurements.

\begin{tabular}{|c|c|c|c|c|}
\hline Power transmission system & Capacity (A, kV, MW, Hz) & Distance from the cable $(\mathrm{m})$ & Magnetic induction $(\mu \mathrm{T})$ & Reference \\
\hline \multicolumn{3}{|c|}{ Earth's magnetic field (GMF) } & $30-70 \mu \mathrm{T}$ & Heilig, 2018 \\
\hline \multirow[t]{4}{*}{ Monopolar DC } & $500 \mathrm{~A}$ & $\begin{array}{c}\text { Surface }(0 \mathrm{~m}) \\
5 \mathrm{~m} \text { above } \\
20 \mathrm{~m} \text { above }\end{array}$ & $\begin{array}{c}2000 \mu T \\
20 \mu T \\
5 \mu T\end{array}$ & \multirow[t]{2}{*}{$\begin{array}{l}\text { ACRES, } 2006 \text { in } \\
\text { Meißner } \text { et } a \text { l., } \\
2006\end{array}$} \\
\hline & $\begin{array}{c}1200 \mathrm{~A} \\
(312 \mathrm{MW} \text { at } 260 \mathrm{kV} ; 370 \mathrm{MW} \\
\text { at } 280 \mathrm{kV})\end{array}$ & $\begin{array}{c}\text { Surface } \\
5 \mathrm{~m} \text { above }\end{array}$ & $\begin{array}{c}5000 \mu \mathrm{T} \\
50 \mu \mathrm{T}\end{array}$ & \\
\hline & $1500 \mathrm{~A}$ & $\begin{array}{c}\text { On the seabed } \\
5 \mathrm{~m} \text { above the seabed } \\
200 \mathrm{~m} \text { above the seabed } \\
\text { (burial depth not found) }\end{array}$ & $\begin{array}{l}300 \mu \mathrm{T} \\
50 \mu \mathrm{T} \\
13 \mu \mathrm{T}\end{array}$ & $\begin{array}{l}\text { Koops, } 2000 \text { in } \\
\text { Meißner et al., } \\
2006\end{array}$ \\
\hline & & $\begin{array}{c}\text { Surface } \\
20 \mathrm{~m} \text { from the cable }\end{array}$ & $\begin{array}{l}>200 \mu \mathrm{T} \\
<20 \mu \mathrm{T}\end{array}$ & \multirow[t]{3}{*}{$\begin{array}{l}\text { Otremba et al., } \\
2019\end{array}$} \\
\hline $\begin{array}{l}\text { DC double case system } \\
\text { (separated by } 10 \mathrm{~m} \text { ) }\end{array}$ & $1330 \mathrm{~A}$ & $\begin{array}{c}\text { Surface } \\
5 \mathrm{~m} \text { from one cable }\end{array}$ & $\begin{array}{l}>500 \mu \mathrm{T} \\
<50 \mu \mathrm{T}\end{array}$ & \\
\hline AC three-phase & & $\begin{array}{l}\text { Surface } \\
0.4 \mathrm{~m}\end{array}$ & $\begin{array}{c}>250 \\
0 \mu \mathrm{T} \\
(+\mathrm{GMF})\end{array}$ & \\
\hline
\end{tabular}




\begin{tabular}{|c|c|c|c|c|}
\hline & $132 \mathrm{kV}, 350 \mathrm{~A}, 50 \mathrm{~Hz}$ & Surface & $1.6 \mu \mathrm{T}$ & CMACS, 2003 \\
\hline & $11 \mathrm{kV}, 60 \mathrm{~A}, 50 \mathrm{~Hz}$ & $\begin{array}{c}\text { Surface } \\
5 \mathrm{~m} \text { from the cable }\end{array}$ & $\begin{array}{l}0.055 \mu \mathrm{T} \\
0.046 \mu \mathrm{T}\end{array}$ & \\
\hline & $33 \mathrm{kV}, 50 \mathrm{~A}, 50 \mathrm{~Hz}$ & $\begin{array}{c}\text { Surface } \\
5 \mathrm{~m} \text { from the cable } \\
400 \mathrm{~m} \text { from the cable }\end{array}$ & $\begin{array}{c}0.050 \mu \mathrm{T} \\
0.012 \mu \mathrm{T} \\
0.00005 \mu \mathrm{T} \\
\text { (background levels) }\end{array}$ & \\
\hline AC XLEP & $33 \mathrm{kV}, 641 \mathrm{~A}$ & $\begin{array}{c}\text { Surface } \\
2.5 \mathrm{~m} \text { from the cable }\end{array}$ & $\begin{array}{c}1.7 \mu \mathrm{T} \\
0.61 \mu \mathrm{T}\end{array}$ & \\
\hline $\begin{array}{l}\text { AC three-core PEX-composite } \\
\text { cable }\end{array}$ & $600 \mathrm{~A}, 132 \mathrm{kV}$ & $2 \mathrm{~m}$ above the cable & $5 \mu \mathrm{T}$ & $\begin{array}{l}\text { HVIT, } 2004 \text { in } \\
\text { Meißner et al., } \\
2006\end{array}$ \\
\hline $\begin{array}{l}\text { AC cables (values obtained from } \\
\text { a model based on the } \\
\text { properties of } 10 \text { cables) }\end{array}$ & & $\begin{array}{l}\text { On the seabed (cable buried at } 1 \\
\text { m depth) }\end{array}$ & $7.85 \mu \mathrm{T}$ & $\begin{array}{l}\text { Normandeau et } \\
\text { al., } 2011\end{array}$ \\
\hline $\begin{array}{l}\text { DC cables (values obtained } \\
\text { from a model based on the } \\
\text { properties of } 8 \text { cables) }\end{array}$ & & $\begin{array}{l}\text { On the seabed (cable buried at } 1 \\
\text { m depth) }\end{array}$ & $78.27 \mu \mathrm{T}$ & \\
\hline \multirow[t]{3}{*}{ AC three-phase } & 265 A, $33 \mathrm{kV}$ & $\begin{array}{l}\text { On the seabed (cable buried at } \\
1.5 \mathrm{~m} \text { depth) }\end{array}$ & $1.5 \mu \mathrm{T}$ & \multirow{2}{*}{$\begin{array}{l}\text { Gill et al., } 2005 \\
\text { and Gill et al., } \\
2010\end{array}$} \\
\hline & $132.5 \mathrm{~A}, 33 \mathrm{kV}$ & $\begin{array}{l}\text { On the seabed (cable buried at } \\
1.5 \mathrm{~m} \text { depth) }\end{array}$ & $0.9 \mu \mathrm{T}$ & \\
\hline & $350 \mathrm{~A}, 132 \mathrm{kV}$ & Surface & $1.6 \mu \mathrm{T}$ & COWRIE, 2003 \\
\hline \multirow[t]{2}{*}{$\begin{array}{l}\text { HVDC (values obtained from } \\
\text { field measurement) }\end{array}$} & $345 \mathrm{~A}, 300 \mathrm{kV}$ & $\begin{array}{l}\text { On the seabed (cable buried at } \\
\text { about } 2 \mathrm{~m} \text { depth) }\end{array}$ & $\begin{array}{c}3.8 \mu \mathrm{T} \text { (average deviation from the GMF for } \\
\text { several measurements along the cable), } \\
\max =18.7 \mu \mathrm{T}\end{array}$ & $\begin{array}{l}\text { Hutchison et al., } \\
2018\end{array}$ \\
\hline & $1320 \mathrm{~A}, 500 \mathrm{kV}$ & $\begin{array}{c}\text { On the seabed (cable buried at } \\
\text { about } 1.2-1.8 \mathrm{~m} \text { depth) }\end{array}$ & $\begin{array}{c}6.8 \mu \mathrm{T} \text { (average deviation from the GMF for } \\
\text { several measurements along the cable), }\end{array}$ & $\begin{array}{l}\text { Hutchison et al., } \\
2018\end{array}$ \\
\hline
\end{tabular}




\begin{tabular}{|l|c|c|c|}
\hline & & & $\max =20.7 \mu \mathrm{T}$ \\
\hline AC Three-phase cables & $502 \mathrm{~A}$ per conductor & On the seabed & 0.005 to $3.1 \mu \mathrm{T}$ (average values) \\
\hline
\end{tabular}

Table 2. Summary of studies investigating the effects of artificial magnetic fields. 


\begin{tabular}{|c|c|c|c|c|c|c|c|c|}
\hline \multirow{2}{*}{$\begin{array}{l}\text { Type of } \\
\text { response } \\
\text { considered }\end{array}$} & \multirow[b]{2}{*}{ Group } & \multirow[b]{2}{*}{ Species } & \multirow[b]{2}{*}{ Life stage } & \multirow[b]{2}{*}{ Lifestyle } & \multicolumn{2}{|c|}{$\begin{array}{c}\text { Characteristics of AMF } \\
\text { exposure }\end{array}$} & \multirow[b]{2}{*}{ Observed effects } & \multirow[b]{2}{*}{ Reference } \\
\hline & & & & & Duration & $\begin{array}{c}\text { Magnetic } \\
\text { induction } \\
(\mathrm{mT})\end{array}$ & & \\
\hline \multirow{7}{*}{ Survival } & \multirow{4}{*}{ Crustaceans } & $\begin{array}{l}\text { North Sea prawn } \\
\text { (Crangon crangon) }\end{array}$ & \multirow{9}{*}{ Adult } & \multirow{4}{*}{ Vagile epifauna } & 49 days & \multirow{5}{*}{$3.7 \mathrm{mT} \mathrm{DC}$} & \multirow{7}{*}{ None } & \multirow{5}{*}{$\begin{array}{l}\text { Bochert and } \\
\text { Zettler (2006) }\end{array}$} \\
\hline & & $\begin{array}{c}\text { Isopod } \\
\text { (Saduria entomon) }\end{array}$ & & & 93 days & & & \\
\hline & & $\begin{array}{c}\text { Isopod } \\
\text { (Sphaeroma } \\
\text { hookeri) }\end{array}$ & & & 34 days & & & \\
\hline & & $\begin{array}{c}\text { Round crab } \\
\text { (Rhithropanopeus } \\
\text { harrisii) }\end{array}$ & & & 57 days & & & \\
\hline & \multirow{2}{*}{ Molluscs } & $\begin{array}{c}\text { Blue mussel } \\
\text { (Mytilus edulis) }\end{array}$ & & Sessile epifauna & 52 days & & & \\
\hline & & $\begin{array}{c}\text { Baltic clam } \\
\text { (Limecola balthica) }\end{array}$ & & \multirow[b]{2}{*}{$\begin{array}{l}\text { Sedentary } \\
\text { endofauna }\end{array}$} & 12 days & & & \multirow[b]{2}{*}{$\begin{array}{c}\text { Jakubowska et } \\
\text { al. (2019) }\end{array}$} \\
\hline & Polychaetes & $\begin{array}{l}\text { Ragworm } \\
\text { (Hediste } \\
\text { diversicolor) }\end{array}$ & & & 12 days & $\begin{array}{l}0.85 \text { to } 1.05 \\
\text { mT } 50 \mathrm{~Hz} A C\end{array}$ & & \\
\hline \multirow[b]{2}{*}{ Physiological } & \multirow[b]{2}{*}{ Crustaceans } & $\begin{array}{l}\text { North Sea prawn } \\
\text { (Crangon crangon) }\end{array}$ & & \multirow[b]{2}{*}{ Vagile epifauna } & \multirow[b]{2}{*}{3 hours } & \multirow[b]{2}{*}{$\begin{array}{c}3.2 \mathrm{mT} \mathrm{DC} \text { and } \\
50 \mathrm{~Hz} \mathrm{AC}\end{array}$} & \multirow[b]{2}{*}{$\begin{array}{l}\text { No effects on oxygen } \\
\text { consumption rate }\end{array}$} & \multirow[b]{2}{*}{$\begin{array}{l}\text { Bochert and } \\
\text { Zettler (2006) }\end{array}$} \\
\hline & & $\begin{array}{c}\text { Baltic prawn } \\
\text { (Palaemon squilla) }\end{array}$ & & & & & & \\
\hline Physiological & Crustaceans & $\begin{array}{c}\text { Edible crab } \\
\text { (Cancer pagurus) }\end{array}$ & Juvenile & Vagile epifauna & 6 hours & $2.8 \mathrm{mT} \mathrm{DC}$ & $\begin{array}{l}\text { No effects either on oxygen } \\
\text { consumption rate and }\end{array}$ & $\begin{array}{l}\text { Scott et al. } \\
\text { (2018) }\end{array}$ \\
\hline
\end{tabular}




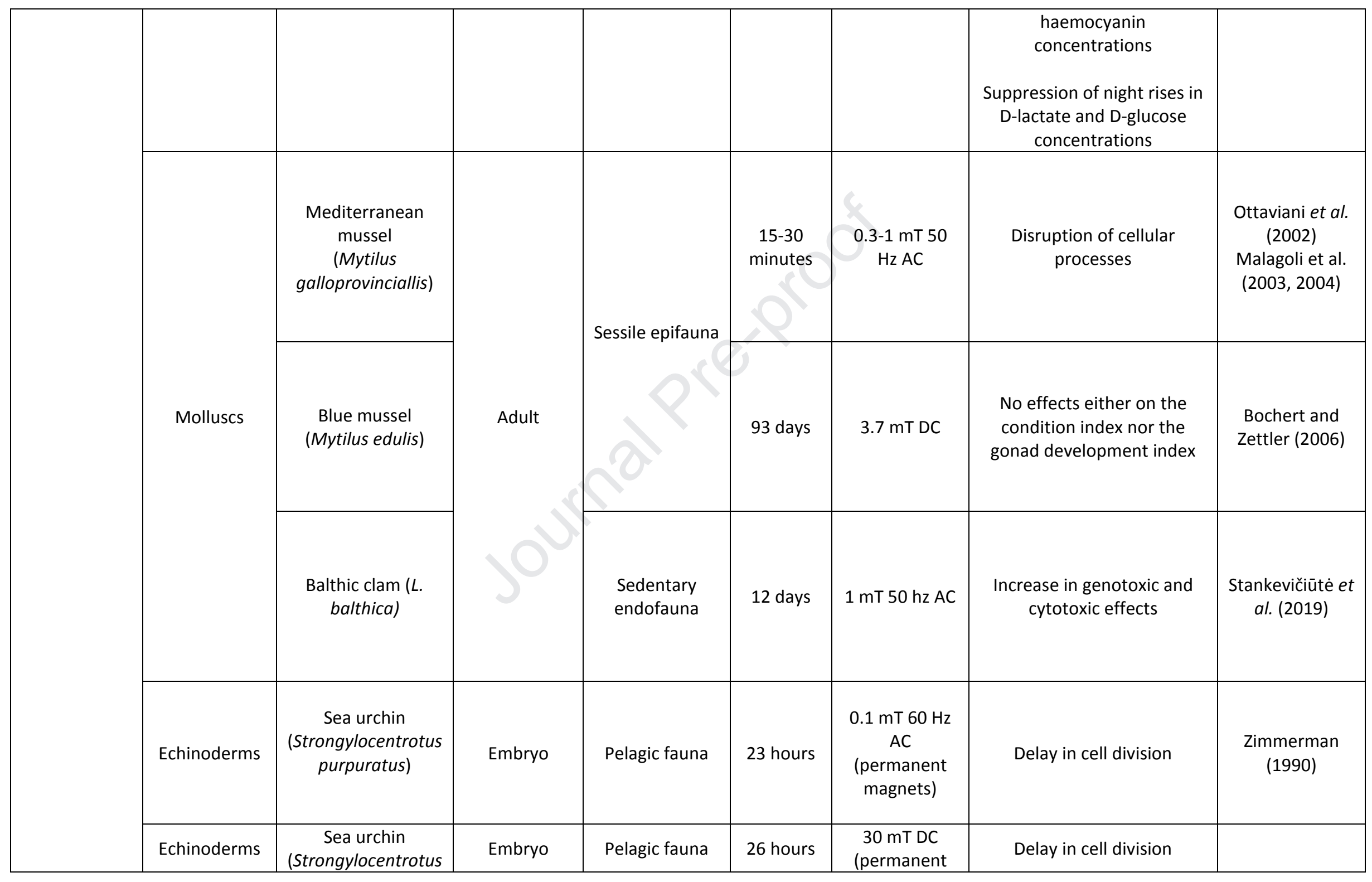




\begin{tabular}{|c|c|c|c|c|c|c|c|c|}
\hline & & purpuratus) & & & & magnets) & & \multirow{3}{*}{$\begin{array}{c}\text { Levin and Ernst } \\
\text { (1997) }\end{array}$} \\
\hline & & \multirow{2}{*}{$\begin{array}{c}\text { Sea urchin } \\
\text { (Lytechinus pictus) }\end{array}$} & & & \multirow[b]{2}{*}{$\begin{array}{l}48-94 \\
\text { hours }\end{array}$} & $\begin{array}{l}30 \text { mT DC } \\
\text { (permanent } \\
\text { magnets) }\end{array}$ & $\begin{array}{c}\text { Delay in cell division } \\
\text { Increase in development } \\
\text { abnormalities }\end{array}$ & \\
\hline & & & & & & $\begin{array}{c}0.39 \mathrm{mT} \text { AC } 60 \\
\mathrm{~Hz} \\
\text { (permanent } \\
\text { magnets) }\end{array}$ & $\begin{array}{l}\text { Increase in development } \\
\text { abnormalities }\end{array}$ & \\
\hline & \multirow[t]{2}{*}{ Polychaetes } & \multirow{2}{*}{$\begin{array}{l}\text { Ragworm } \\
\text { (Hediste } \\
\text { diversicolor) }\end{array}$} & \multirow[t]{2}{*}{ Adult } & \multirow[t]{2}{*}{$\begin{array}{l}\text { Sedentary } \\
\text { endofauna }\end{array}$} & 8 days & \multirow[t]{2}{*}{$1 \mathrm{mT} 50 \mathrm{~Hz} \mathrm{AC}$} & $\begin{array}{l}\text { No effects on food } \\
\text { consumption and respiration } \\
\text { rates but increase in } \\
\text { ammonia excretion }\end{array}$ & $\begin{array}{c}\text { Jakubowska et } \\
\text { al. (2019) }\end{array}$ \\
\hline & & & & & 12 days & & $\begin{array}{l}\text { Increase in genotoxic and } \\
\text { cytotoxic effects }\end{array}$ & $\begin{array}{c}\text { Stankevičiūtè et } \\
\text { al. (2019) }\end{array}$ \\
\hline \multirow{7}{*}{ Behavioural } & \multirow{7}{*}{ Crustaceans } & Edible crab & \multirow[t]{7}{*}{ Juvenile } & & 7 hours & \multirow[t]{2}{*}{$2.8 \mathrm{mT} \mathrm{DC}$} & Attraction behaviour & \multirow{2}{*}{$\begin{array}{l}\text { Scott et al. } \\
\quad(2018)\end{array}$} \\
\hline & & & & & 24 hours & & $\begin{array}{c}\text { Suppression of side selection } \\
\text { behaviour }\end{array}$ & \\
\hline & & $\begin{array}{c}\text { Spiny cheek } \\
\text { crayfish } \\
\text { (Oronectes limosus) }\end{array}$ & & & 24 hours & $0.8 \mathrm{mT}$ & Attraction behaviour & $\begin{array}{l}\text { Tanski et al. } \\
\text { (2005) }\end{array}$ \\
\hline & & $\begin{array}{c}\text { Spiny lobster } \\
\text { (Panulirus argus) }\end{array}$ & & Vagile epifauna & $\begin{array}{c}15 \\
\text { minutes }\end{array}$ & $703.1 \mathrm{mT}$ & Repulsion behaviour & $\begin{array}{l}\text { Ernst and } \\
\text { Lohmann } \\
(2018)\end{array}$ \\
\hline & & $\begin{array}{c}\text { Freshwater crab } \\
\text { (Barythelphusa } \\
\text { canicularis) } \\
\end{array}$ & & & $2 \mathrm{~h} 30 \mathrm{~min}$ & $50 \mathrm{~Hz} \mathrm{AC}$ & $\begin{array}{c}\text { Attraction and aggregation } \\
\text { behaviour }\end{array}$ & $\begin{array}{l}\text { Rosaria and } \\
\text { Martin (2010) }\end{array}$ \\
\hline & & $\begin{array}{l}\text { North Sea prawn } \\
\text { (Crangon crangon) }\end{array}$ & & & 15 hourc & $27 \mathrm{mT} R \mathrm{c}$ & No effects on spatial & Bochert and \\
\hline & & $\begin{array}{c}\text { Isopod } \\
\text { (Saduria entomon) }\end{array}$ & & & 1.3 nours & $2.1 \mathrm{mILC}$ & distribution & Zettler (2006) \\
\hline Behavioural & Crustaceans & $\begin{array}{c}\text { Round crab } \\
\text { (Rhithropanopeus }\end{array}$ & & & 1.5 hours & $2.7 \mathrm{mT} \mathrm{DC}$ & $\begin{array}{l}\text { No effects on spatial } \\
\text { distribution }\end{array}$ & $\begin{array}{l}\text { Bochert and } \\
\text { Zettler (2006) }\end{array}$ \\
\hline
\end{tabular}




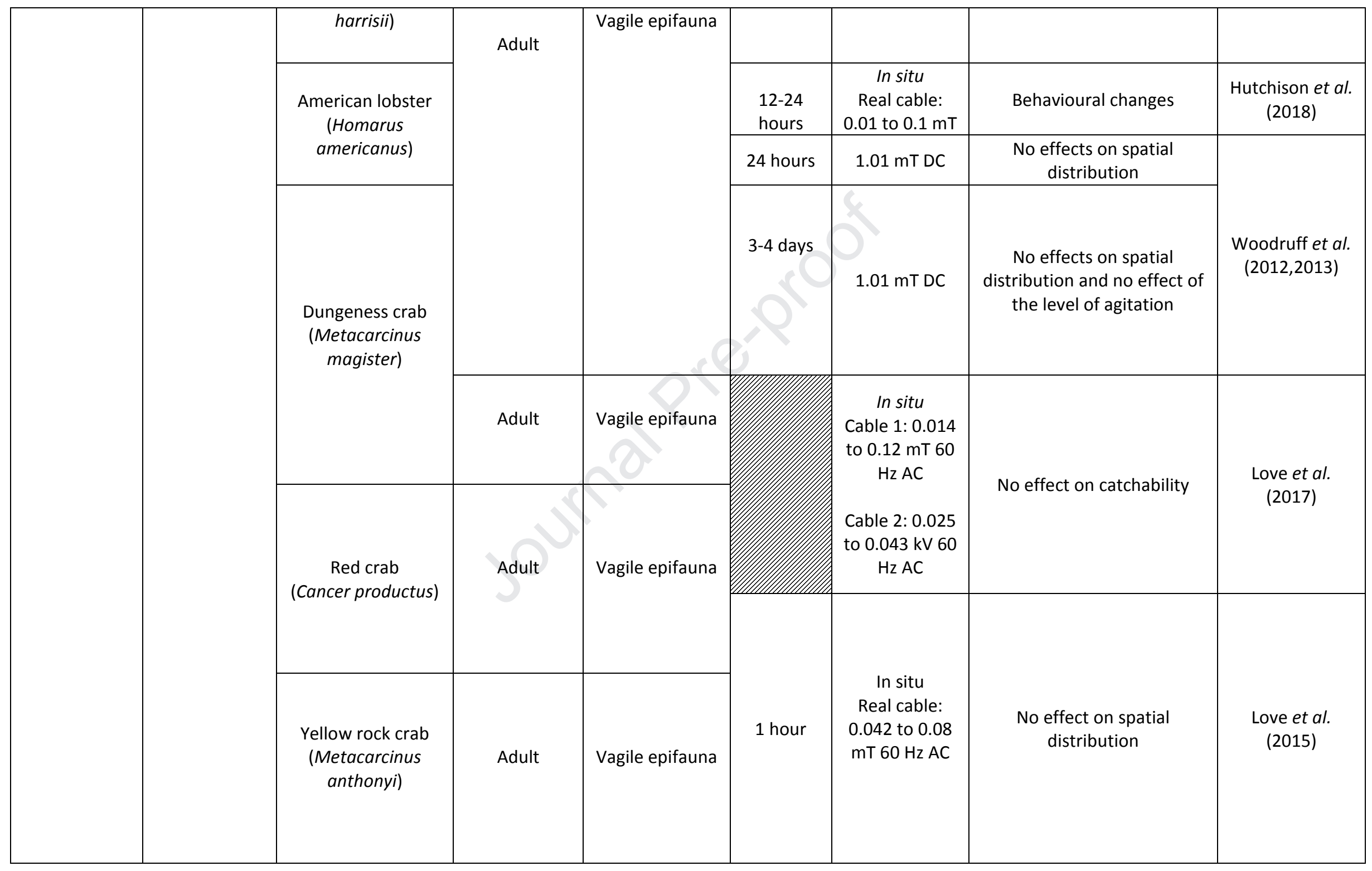




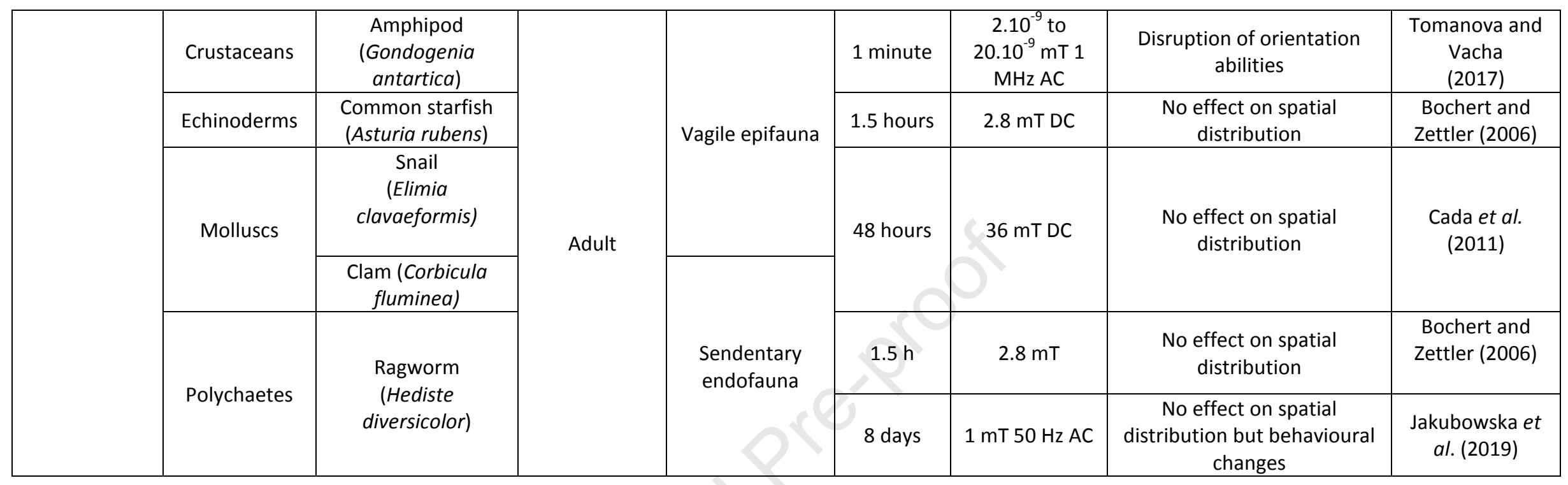




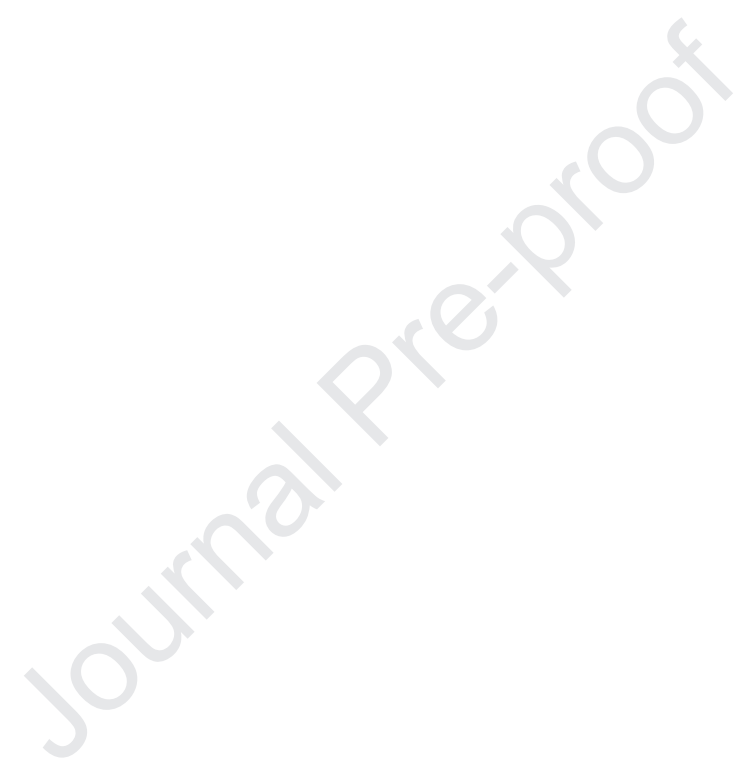


Figure 1. Scheme of the electrical connection of an offshore wind park and associated voltages (V) (inspired by https://rtefrance.com).

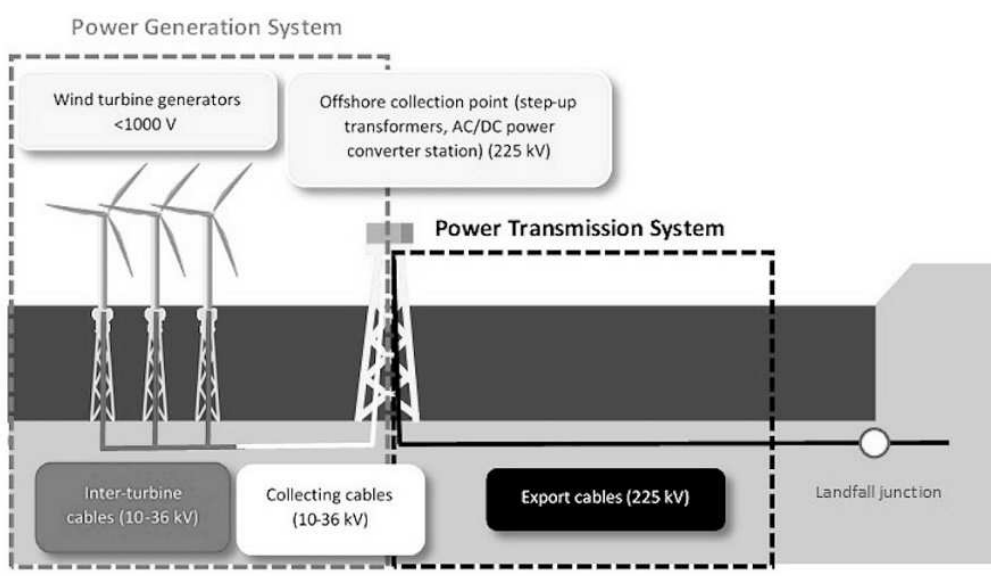

Figure 2. General distribution of some invertebrate species according to the theoretical values of magnetic fields emitted by $225 \mathrm{kV}$ buried $(1 \mathrm{~m})$ and unburied single-conductor cables, energized with an intensity of $1000 \mathrm{~A}$ (diameter: $27 \mathrm{~cm}$ ). Magnetic field intensities were calculated with the following formula: $B=\frac{\mu \mu 0}{2 \pi r} I ; B$ is the magnetic induction $(T), \mu$ is the relative magnetic permeability of the medium, $\mu_{0}$ is the vacuum permeability $(4 \pi \cdot 10-7 \mathrm{~V} \mathrm{~s} \mathrm{A-1} \mathrm{m-1),} l$ is the current intensity $(A)$ and $r$ is the distance from the centre of the wire $(\mathrm{m})$ (formula from Otremba et al., 2019).

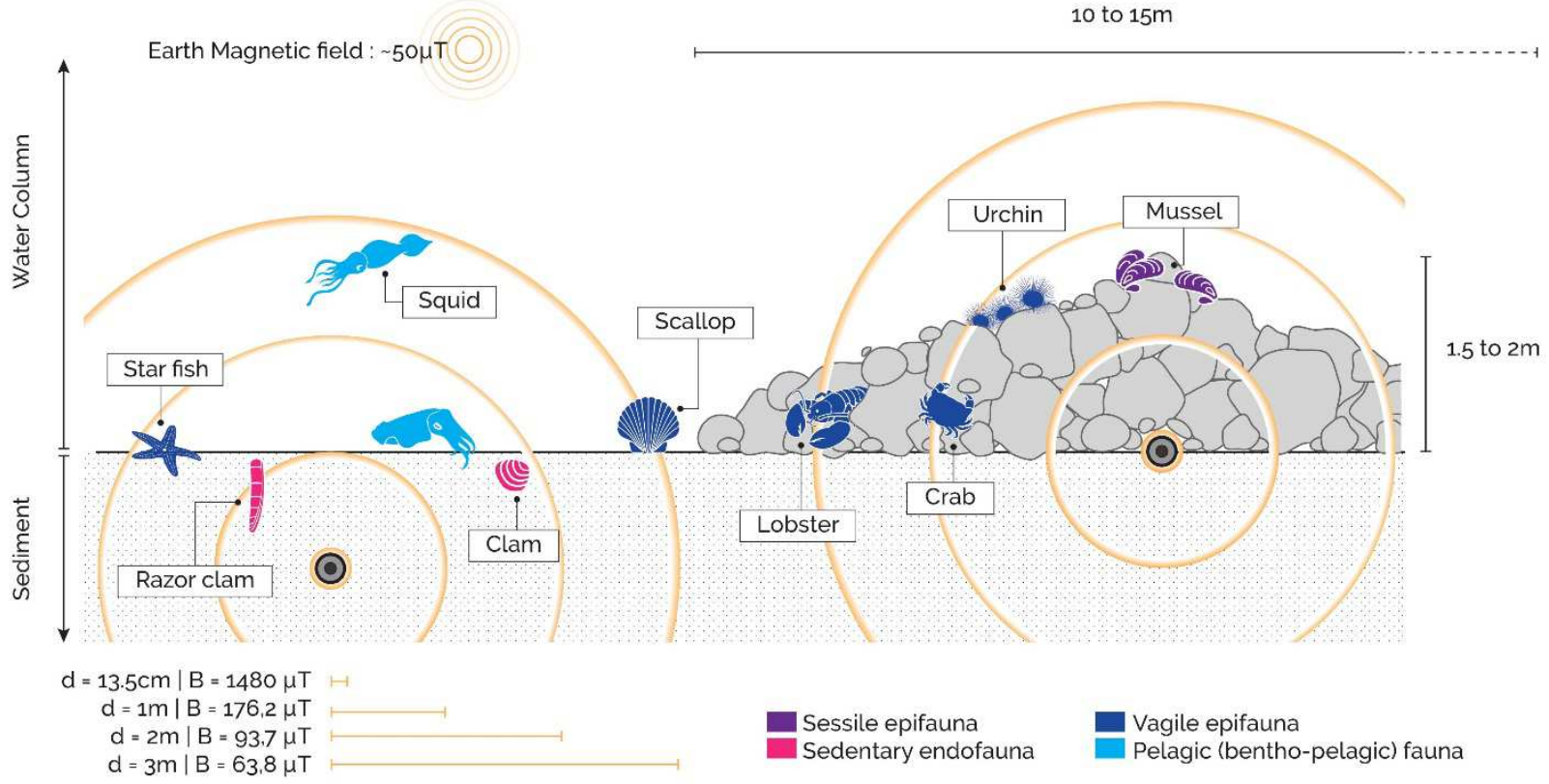




\section{Highlights}

- Submarine power cables produce both magnetic and electric fields

- Marine invertebrate species inhabit the benthic or sediment compartment where cables emissions would be the strongest.

- Studies are scarce and invertebrate sensitivity to both natural and artificial sources of magnetic and electric fields is poorly documented.

- Marine invertebrates should prioritised in future research studies according to their proximity to the cable and the duration of their exposure. 


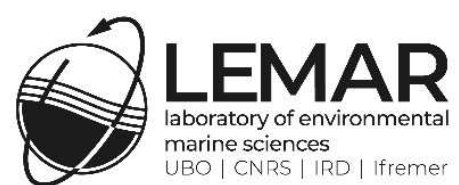

LEMAR (UMR CNRS/UBO/IRD/Ifremer 6539)

Laboratoire des sciences de l'environnement marin

Institut Universitaire Européen de la Mer

Technopole Brest Iroise, Place N. Copernic

F-29280 Plouzané

Brest, $9^{\text {th }}$ March 2020

Dear Editor-in-Chief,

Due to conflict of interest, we would prefer not to be reviewed by Bastien Taormina and Antoine Carlier. We thank you for your understanding.

Yours sincerely,

Luana Albert 